\title{
Canalização: fenótipos robustos como consequência de características da rede de regulação gênica
}

\author{
Vitor Hugo Louzada Patricio \\ DisSERTAÇÃO APRESENTADA \\ $\mathrm{AO}$ \\ Programa Interunidades em Bioinformática \\ DA \\ Universidade de São Paulo \\ Programa: Mestrado em Bioinformática \\ Orientador: Prof. Dr. Ronaldo Fumio Hashimoto \\ Este trabalho recebeu auxílio financeiro da CAPES e da FAPESP
}

São Paulo, março de 2011 



\title{
Canalização: estabilidade fenotípica como consequência de características da rede de regulação gênica
}

\author{
Este exemplar corresponde à redação \\ final do projeto de Dissertação submetida à comissão \\ julgadora apresentado por Vitor Hugo Louzada Patricio \\ ao Programa de Mestrado Interunidades \\ em Bioinformática da Universidade de São Paulo.
}

Banca Examinadora:

- Prof. Dr. Ronaldo Fumio Hashimoto(orientador) - IME-USP.

- Prof. Dr. Ney Lemke - IB-UNESP.

- Profa. Dra. Tie Koide - FMRP-USP. 

"To really succeed, one must enjoy eating poison." Antigo provérbio Klingon 
Aos meus pais, 


\section{Agradecimentos}

É melhor começar cronologicamente.

Agradeço a Deus por tudo. Por tudo até, por tudo durante e por tudo o que vier. Eu não diria que até aqui Deus me ajudou, mas que tenho certeza que a presença de Deus é constante em qualquer coisa que eu faça.

Aos meus pais, por todo o apoio que me deram, por terem paciência comigo, por terem sido minha primeira agência patrocinadora, por terem me deixado sair de casa tão novo e por terem estado ao meu lado em cada momento de alegria e tristeza.

Aos grandes amigos da Fundação Nerv. As partes boas deste trabalho não teriam existido com tudo o que aprendi com vocês, e eu não teria consigo passar pelas partes chatas sem toda sua, digamos, presença de espirito.

À querida família Fumo e agregados, que alegremente me recebeu quando mudei para São Paulo e por sempre cederem sua atenção e seu sofá.

À todos envolvidos na minha adaptação e formação na USP. À Patrícia, por ter segurado minha matrícula enquanto a Unicamp e a USP não se entendiam e, claro, ao meu Orientador. Inumeráveis foram os dias em que ele me recebeu com toda paciência para ouvir meus poucos avanços e me orientou no sentido certo. Apesar dele achar que eu trabalhei de forma independente, posso dizer que aprendi muito com nossas reuniões. Também agradeço a paciência e a ajuda de todo o pessoal do laboratório, sempre presentes seja para uma carona, uma colaboração ou um café.

Àquela que pacientemente corrigiu o português deste trabalho (exceto esta seção, razão pela qual a mesma possui tantas crases erradas). Pacientemente aguentou toda a minha preocupação, todas as vezes que deixei de dar atenção e todas as minha ogrices. Sem você do meu lado, coração, eu não teria chegado até aqui.

Ao pessoal do trabalho, grandes nerds que caíram de paraquedas na minha vida e que aguentaram todo meu stress e preocupação na reta final desse trabalho.

Como podemos perceber, eu evitei nomes nesta seção. Seria injusto não citar os nomes também de todos aqueles que, mesmo sem perceberem, contribuíram para a construção desta dissertação.

Simplesmente, obrigado. 


\section{Resumo}

Em sistemas biológicos, o estudo da estabilidade das redes de regulação gênica é visto como uma contribuição importante que a Matemática pode proporcionar a pesquisas sobre câncer e outras doenças genéticas. Neste trabalho, utilizamos o conceito de "canalização" como sinônimo de estabilidade em uma rede biológica. Como as características de uma rede de regulação canalizada ainda são superficialmente compreendidas, estudamos esse conceito sob o ponto de vista computacional: propomos um modelo matemático simplificado para descrever o fenômeno e realizamos algumas análises sobre o mesmo. Mais especificamente, a estabilidade da maior bacia de atração das redes Booleanas - um clássico paradigma para a modelagem de redes de regulação - é analisada. Os resultados indicam que a estabilidade da maior bacia de atração está relacionada com dados biológicos sobre o crescimento de colônias de leveduras e que considerações sobre a interação entre as funções Booleanas e a topologia da rede devem ser realizadas conjuntamente na análise de redes estáveis. 


\begin{abstract}
In biological systems, the study of gene regulatory networks stability is seen as an important contribution that Mathematics can make to cancer research and that of other genetic diseases. In this work, we consider the concept of "canalization" as a consequence of stability in gene regulatory networks. The characteristics of canalized regulatory networks are superficially understood. Hence, we study the canalization concept under a computational framework: a simplified model is proposed to describe the phenomenon using Boolean Networks - a classical paradigm to modeling regulatory networks. Specifically, the stability of the largest basin of attraction in gene regulatory networks is analyzed. Our results indicate that the stability of the largest basin of attraction is related to biological data on growth of yeast colonies, and that thoughts about the interaction between Boolean functions and network topologies must be given in the analysis of stable networks.
\end{abstract}




\section{Conteúdo}

1 Introdução 1

2 Canalização de Características $\quad 3$

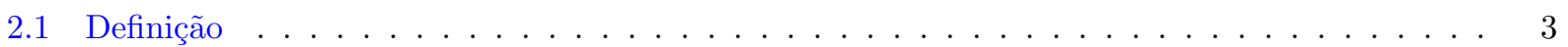

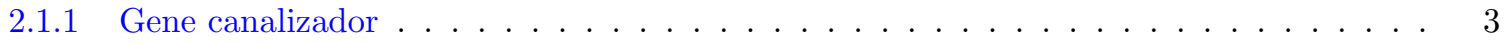

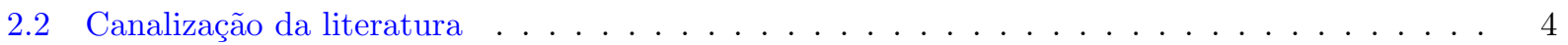

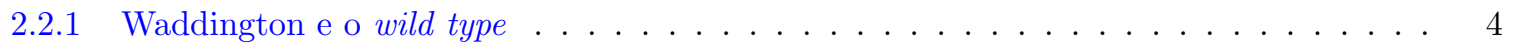

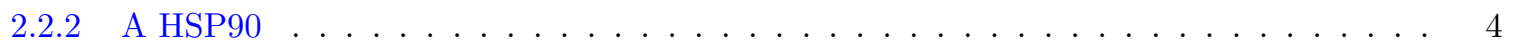

$2.2 .3 \quad \mathrm{Na}$ levedura . . . . . . . . . . . . . . . . . . . . . . . . . . 4

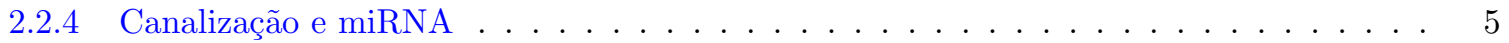

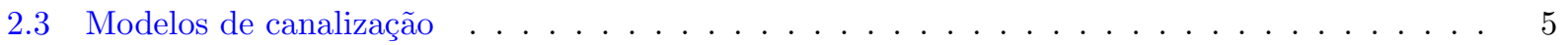

2.4 Funções Canalizadoras e canalização . . . . . . . . . . . . . . . . . . . . . . . 6

3 Redes Booleanas $\quad 7$

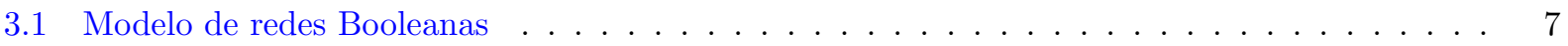

3.1.1 Redes Booleanas com pertubação . . . . . . . . . . . . . . . . . . . . . 8

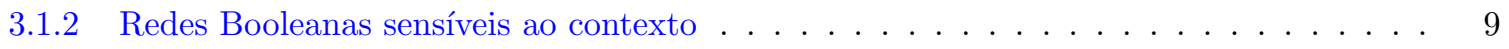

3.1.3 Redes Booleanas com limiar . . . . . . . . . . . . . . . . . . . . . . . . . . 9

3.2 Redes Booleanas na literatura . . . . . . . . . . . . . . . . . . . . . 10

3.2.1 Trabalhos sobre a estabilidade de redes Booleanas . . . . . . . . . . . . . . . 11

3.2.2 Trabalhos sobre controle de redes Booleanas . . . . . . . . . . . . . . . . . . . 11

4 Funções Booleanas $\quad 13$

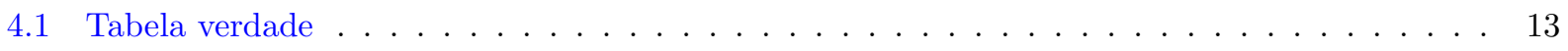

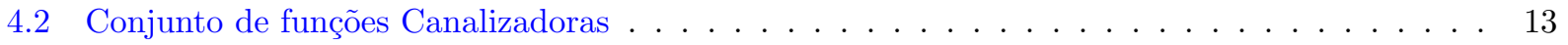

4.3 Conjunto de funções canalizadoras aninhadas . . . . . . . . . . . . . . . . . . . 14

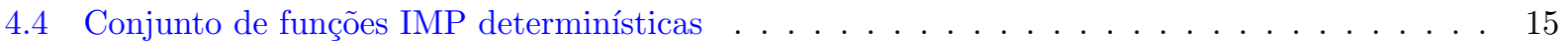

4.5 Classe de funções Post . . . . . . . . . . . . . . . . . . . . . . . . 17

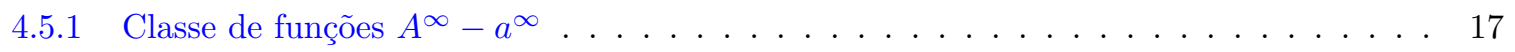

4.5.2 Classe de funções Post $A^{2}-a^{2} \ldots \ldots \ldots \ldots \ldots \ldots \ldots \ldots \ldots$

4.6 Conjunto de funções de limiar simplificada $\ldots \ldots \ldots \ldots \ldots \ldots \ldots \ldots$

4.7 Interseções entre conjuntos de funções Booleanas . . . . . . . . . . . . . . . . . 18

4.8 Medidas em redes de funções Booleanas . . . . . . . . . . . . . . . . . . . . . . . . 19

4.8 .1 Quantidade de atratores . . . . . . . . . . . . . . . . 20

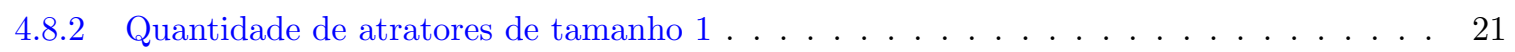


4.8.3 Tamanho da maior bacia de atração . . . . . . . . . . . . . . . . . . . . 21

4.9 Discussão . . . . . . . . . . . . . . . . . . . . . . . . . . . 23

5 Canalização pelo tamanho da bacia de atração 27

5.1 Simplificações utilizadas . . . . . . . . . . . . . . . . . . . . . . . 27

5.2 Estabilidade de uma TBN em relação a modificações estruturais . . . . . . . . . . . . . . . . 27

5.2.1 Resistência do atrator majoritário a uma única modificação . . . . . . . . . . . . . 28

5.2 .2 Resistência do atrator majoritário a $m$ modificações . . . . . . . . . . . . . . . . . . . 29

5.3 Genes e interações que regulam a estabilidade de uma TBN . . . . . . . . . . . . . . . . . . 29

5.3.1 Interações entre os genes como reguladoras da estabilidade . . . . . . . . . . . . 30

5.3.2 Genes como reguladores da estabilidade . . . . . . . . . . . . . . . . . . . . 31

5.4 Conclusão . . . . . . . . . . . . . . . . . . . . . . . . . 34

6 Funções Booleanas e topologias da rede de regulação 37

6.1 Redes Complexas . . . . . . . . . . . . . . . . . . . . . . . . 38

6.1 .1 Redes livres de escala . . . . . . . . . . . . . . . . . . . . . . . . . 38

6.1.2 Redes com um Hub central . . . . . . . . . . . . . . . . . . . . . . 38

6.1 .3 Redes em árvore . . . . . . . . . . . . . . . . . . . . . . . . . . . . . 39

6.1.4 Redes Complexas e redes Booleanas na literatura . . . . . . . . . . . . . . . . . 40

6.2 Metodologia . . . . . . . . . . . . . . . . . . . . . . 40

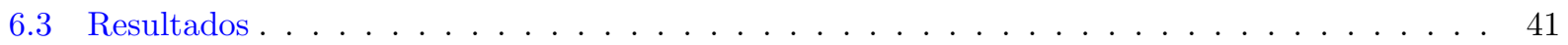

6.4 Discussão . . . . . . . . . . . . . . . . . . . . . . . . . . . 43

6.5 Conclusão . . . . . . . . . . . . . . . . . . . . . . . . . . . . 44

7 Conclusão 45

$\begin{array}{ll}\text { Bibliografia } & 47\end{array}$ 


\section{Capítulo 1}

\section{Introdução}

Robustez é uma qualidade considerada necessária para qualquer rede que se disponha a funcionar no mundo real. Em sistemas biológicos, o estudo da robustez das redes de regulação gênica é visto como uma contribuição importante que a Matemática pode proporcionar a pesquisas sobre câncer e outras doenças genéticas [29].

O relacionamento entre os termos "robustez", "estabilidade" e, em um nível mais biológico, "homeostase" e "canalizaçãa" é controverso. Embora muitas vezes tratados como sinônimos, alguns autores - como Kitano [30] no trabalho de 2007 - apresentação distinções para os termos. Neste trabalho, no entanto, utilizamos o conceito de "canalização" como sinônimo de estabilidade e robustez.

Explorando o termo "estabilidade", é possível perceber o quanto sua definição é instável. Em uma rede de regulação, a estabilidade pode ser definida de diversas formas, como, por exemplo: a resiliência da topologia da rede à remoção de uma conexão, a quantidade de funções redundantes, a habilidade de executar a mesma atividade após uma pertubação e muitas outras. Embora similares, essas definições carregam implicações matemáticas distintas.

O conceito de "canalização" foi apresentado por Waddington [59] em 1942, como parte dos argumentos que sustentavam sua proposta de herança de características adquiridas. Canalização significa robustez do fenótipo em relação a variações no genótipo. O Capítulo 2 é dedicado à explicação desse conceito e à apresentação de algumas pesquisas biológicas recentes sobre o assunto.

Apesar de se tratar de um conceito clássico em biologia teórica, a caracterização de uma rede de regulação gênica que apresenta canalização ainda é um tema em discussão. A identificação dos primeiros exemplos de redes canalizadas data de 1997 e mesmo esses exemplos são contestados. A compreensão das características, da formação e da ruptura de uma rede de regulação canalizada ainda é um tópico superficialmente compreendido.

Complementando trabalhos anteriores, em que realizamos análises sobre as interações gênicas em redes de regulação [15] e o desempenho de algoritmos de inferência de redes [34], o objetivo deste trabalho é estudar o conceito biológico de canalização de características em redes de regulação gênica. Em outras palavras, propomos um modelo matemático simplificado para descrever o fenômeno e realizamos algumas análises, matemáticas e biológicas, sobre o mesmo.

Para modelar a canalização, trabalhamos com redes Booleanas, uma forma clássica na modelagem de redes de regulação gênica. No escopo, diversos tipos de funções Booleanas são estudadas. Os Capítulos 3 e 4 se tratam de uma revisão das redes Booleanas e das funções Booleanas estudadas.

Os resultados de nossas análises indicam duas contribuições relevantes. No Capítulo 5, apresentamos uma proposta de modelo para a canalização, ao considerá-la como uma consequência do tamanho da bacia 
de atração da rede de regulação. Considerações teóricas sobre exemplos de redes Booleanas presentes na literatura são realizadas, indicando a validade do modelo proposto. Já no Capítulo 6, estudamos as relações entre as diferentes topologias de uma rede de regulação e a sua estabilidade. O impacto de diferentes funções Booleanas e topologias na estabilidade da rede é analisado. Os resultados indicam que uma combinação entre topologia e função Booleana que propicia a estabilidade pode ser necessária na criação de canalização em uma rede.

Este trabalho é fundamentado na interdisciplinaridade, mas escrito pela área da computação. Logo, alguns conceitos biológicos podem não ser tão especificados, ao passo que alguns conceitos matemáticos podem ser sobretratados ou indevidamente considerados triviais. Nossa intenção é mostrar como um ponto de vista matemático pode simplificar e contribuir para a compreensão de questões biológicas. 


\section{Capítulo 2}

\section{Canalização de Características}

\subsection{Definição}

Biologicamente, canalização significa robustez ou estabilidade. Nas palavras de Waddington, em 1942, no Artigo "Canalization of development and the inheritance of acquired characters" [59] da Nature:

"(...) They (the organisms) are adjusted so as to bring about one definite end-result regardless of minor variations in conditions during the course of the reaction."

É interessante notar que Waddington formulou esse conceito antes de algumas das maiores descobertas da biologia molecular, como o papel do DNA na hereditariedade (1952) e sua descrição em dupla-hélice (1953). Seu artigo de 1942 [59] está principalmente preocupado em criar uma ponte entre evolucionistas (seguidores dos pensamentos de Darwin) e naturalistas (seguidores dos pensamentos de Lamarck), cuja disputa ainda não estava totalmente resolvida na época ${ }^{1}$. Para tanto, Waddington propõe um mecanismo em que a herança de características adquiridas poderia ser explicada por uma combinação adequada entre canalização e seleção natural.

O termo "robustez" pode ser mais detalhado, entretanto. Canalização significa robustez fenotípica apesar de variação genotípica. Em outras palavras, se uma característica for considerada canalizada ${ }^{2}$, ela permanece ativa mesmo se modificações no conjunto de genes, ou nas relações entre os genes, ocorrerem.

A canalização não faz distinção entre os diversos níveis de interpretação da palavra fenótipo: morfologia, desenvolvimento, propriedades bioquímicas ou fisiológicas e comportamento. Cabe ressaltar, contudo, que o conceito de canalização se aplica quando consideramos apenas uma população e, mesmo assim, pequenas variações no conjunto de genes.

Do ponto de vista evolutivo, se um indivíduo possui uma característica ótima canalizada, ele garante a expressão da mesma apesar de pequenas mutações em seu DNA, o que pode ser uma grande vantagem em um ambiente estável. A seleção natural pode atuar na própria canalização do fenótipo, como argumentado por Waddington, ou de outras formas, como veremos mais adiante.

\subsubsection{Gene canalizador}

Se pensarmos no contexto da rede de regulação gênica do organismo, canalização significa robustez de um fenótipo apesar de pequenas modificações na rede. Mas robusto em relação a quais modificações?

\footnotetext{
${ }^{1}$ Talvez o esteja nem hoje em dia, como indicam algumas descobertas em epigenética [21]

${ }^{2}$ Em inglês, a characteristic is canalized. Nesse caso, traduzir o verbo to be como "está" pode ser um problema, uma vez que se sugere a canalização como algo momentâneo ou provocado. Não sabemos o que provoca a canalização, logo tentaremos evitar esse tipo de construção.
} 
Ao lado do conceito de canalização caminha o conceito de gene canalizador. O gene canalizador seria o promotor da robustez fenotípica, ou pelo menos uma condição necessária para a ocorrência da canalização. No trabalho de Waddington, ambos os conceitos são apresentados como complementares: a canalização é uma consequência da atuação de um gene canalizador.

\subsection{Canalização da literatura}

Para exemplificar a canalização e algumas ideias relacionadas, listamos aqui considerações feitas em alguns trabalhos.

\subsubsection{Waddington e o wild type}

Uma das evidências apresentadas por Waddington [59] como comprovação da existência de canalização é a constância do wild type $e^{3}$ O autor aponta que, na natureza, o wild type de um organismo é praticamente constante em uma determinada população, apesar de conhecidas pequenas variações no DNA de cada indivíduo. Segundo Waddington, esse fenômeno é atribuído à canalização do fenótipo ótimo.

Cabe ressaltar que um fenótipo ótimo não deve, necessariamente, estar canalizado. A canalização seria apenas uma vantagem que garante sua constância em uma população.

\subsubsection{A HSP90}

Uma das descobertas mais interessantes sobre canalização - proclamada [55] como um dos primeiros experimentos documentados sobre o assunto - é o trabalho de 1998 de Rutherford e Lindquist [47] sobre o papel da HSP90 no desenvolvimento embrionário da Drosophila.

A HSP90, também conhecida como Heat-shock protein, tem um papel importante na proteção de um organismo em desenvolvimento. No trabalho, inibições químicas foram realizadas no gene codificador da HSP90, com o objetivo de analisar as consequências no desenvolvimento da Drosophila. Os resultados indicam que alterações diversas foram observadas em várias linhagens da mosca, mesmo após o restabelecimento dos níveis normais de HSP90. Esse resultado experimental é um forte indício de que a HSP90 teria um papel canalizador no desenvolvimento da Drosophila.

Além disso, o artigo também considera uma possível nova função para a canalização: a de armazenamento de mutações. Segundo os autores, a robustez promovida pela canalização de um fenótipo propicia ao organismo armazenar pequenas mutações em seu código genético com o passar das gerações, sem exibir mudanças no fenótipo ótimo. Com uma possível mudança de ambiente, e consequente quebra da canalização, as pequenas alterações acumuladas poderiam ser utilizadas para criar um novo fenótipo, que poderia ser mais adequado ao novo ambiente. Experimentalmente, como é justificado, esse comportamento é observado pelo surgimento de diferentes modificações nos organismos adultos apesar da inibição do mesmo gene.

\subsubsection{Na levedura}

Uma das hipóteses para a explicação da canalização é a redundância na atuação de alguns genes. Se há cópias de um mesmo gene espalhadas pelo genoma, ou se vários genes codificam proteínas de função parecida, a perda de função de alguns elementos desse conjunto redundante não causaria grandes alterações no fenótipo.

Analisando dados de expressão do genoma completo da levedura, Wagner [60] analisa essa hipótese. Em suas próprias palavras:

\footnotetext{
${ }^{3}$ wild type: a forma típica (fenótipo) como uma espécie é encontrada na natureza
} 
"if gene duplications are mostly responsible for robustness, then a correlation is expected between the similarity of two duplicated genes and the effect of mutations in one of these genes."

No entanto, utilizando dados de expressão gênica, esta correlação não é encontrada. Wagner conclui que cópias distintas de um mesmo gene respondem de forma diversa a mutações, o que o leva a deduzir que a hipótese da redundância como causadora da robustez é fraca, já que os genes possuem potenciais funções distintas.

O autor argumenta que outras características da forma de atuação dos genes podem ser responsáveis pela robustez fenotípica, como a complexidade da rede de interações entre os genes.

\subsubsection{Canalização e miRNA}

Em um trabalho de 2006, Hornstein e Noam Shomron [16] relacionaram os miRNAs com a canalização. Segundo evidências apresentadas, posteriormente discutidas por Wu et al. [62], os miRNAs seriam os principais promotores da canalização, em vez dos supostos genes canalizadores.

Entretanto, o estudo de miRNA também trouxe alguns problemas para a canalização recentemente. Em um estudo intitulado Is canalization more than just a beautiful idea? [49] (2010), Sato e Siomi questionam o papel da HSP90 como promotora da canalização. Segundo os autores, essa proteína é também responsável pelo controle de muitos miRNAs. Na sua ausência, esses miRNAs podem ser responsáveis por alterações no DNA da célula, o que implica que as variações fenotípicas encontradas após a inibição da HSP90 seriam antes causadas por novas mutações no DNA, e não por variações presentes anteriormente e inativas.

\subsection{Modelos de canalização}

Acompanhando o desenvolvimento da Bioinformática, modelos que descrevem, ou ao menos incluem, o conceito de canalização de características têm se popularizado nos últimos dez anos.

A discussão introduzida por Emlen et al. [8] em 1998 descreve, dentre diversos pontos, o conceito de canalização como uma característica da complexidade do organismo.

Ainda em 1998, o modelo matemático de Eshel e Matessi [9] descreve a evolução de uma característica canalizada sofrendo seleção em uma população. Um dos problemas enfrentados nessa abordagem é o da construção do mapa "genótipo-fenótipo", problema esse que é enfrentado por todos os modelos posteriores.

No trabalho de Hansen e Wagner [13] em 2000, o mapa genótipo-fenótipo é tratado como uma composição de funções lineares. Recentemente (2009), Tusscher e Hogeweg [56] propuseram um mapa semelhante com funções não lineares. Esses modelos descrevem de forma razoável algumas propriedades da canalização, mas necessitam de parâmetros que dificultam sua validação biológica.

O modelo de Proulx e Phillips [43], de 2005, trata a canalização como uma consequência da rede de interação entre os genes e descreve a evolução da canalização em pequenas redes de interação. Posteriormente, outros modelos [28,44] utilizam-se do mesmo princípio. Em seu abstract, o trabalho de Krimbell e Holt [28] apresenta:

"Our results suggest that the details of genetic architecture can significantly influence the likelihood of niche evolution in novel environments."

O recente trabalho de Buskirk e Steiner [5] (2009) expõe uma abordagem diferenciada para o problema. A partir de 27 estudos em plantas e animais sobre seleção e continuidade do fenótipo sob diversas influências, seu modelo atribui custos de plasticidade fenotípica e canalização para as espécies.

Em geral, os modelos de canalização variam entre diversas estratégias (equações diferenciais, sistemas dinâmicos discretos, entre outros) e especificidades (populações, mapa genótipo-fenótipo, rede de interação 
etc.). Entretanto, poucos desses modelos apresentam uma preocupação clara em descrever dados biológicos, ou estão prontos para serem aplicados nos disponíveis, devido ao excesso de parâmetros muitas vezes presente.

\subsection{Funções Canalizadoras e canalização}

Uma das primeiras formas de tratar a canalização sob o ponto de vista computacional foi introduzida por Kauffman em 1971 [24], através do conceito de função Booleana canalizadora.

Uma função Booleana canalizadora é uma função Booleana completamente determinada por um de seus inputs. As definições de função Booleana, rede Booleana e função canalizadora encontram-se nos Capítulos 3 e 4 .

É possível relacionar funções canalizadoras e canalização de características. Um gene submetido a uma função canalizadora depende de apenas outro gene; portanto, seu estado é estável em relação a modificações em seus outros preditores. Se construirmos uma rede de regulação com muitos genes canalizados, a própria rede torna-se estável em relação a modificações. Ao associarmos o funcionamento de uma rede de regulação a um fenótipo, podemos considerar a presença de funções canalizadoras como a base para a canalização de características.

Como podemos perceber, as funções canalizadoras apresentam uma abordagem bottom-up para a modelagem de canalização ao relacionar genes a fenótipos. Retornaremos a esse tema nos Capítulos 5 e 6 . 


\section{Capítulo 3}

\section{Redes Booleanas}

Muitos modelos matemáticos e computacionais têm sido desenvolvidos para explicar interações gênicas [22] e existe um número considerável de tentativas de modelar redes de expressões de genes, como: grafos dirigidos [22], redes Bayesianas [11], redes lógicas generalizadas [57], equações diferenciais ordinárias [36], redes Booleanas [23] e redes Booleanas probabilísticas [51]. Uma listagem das principais formas de modelagem pode ser encontrada em Schlitt e Brazma [50] e uma listagem com modelos e técnicas de inferência pode ser encontrada em Sima [53].

Embora algumas das hipóteses encontradas via simulações devam ser verificadas posteriormente em laboratório, simulações de modelos computacionais podem reduzir custos pela substituição da utilização de toda a infraestrutura laboratorial para a identificação de hipóteses iniciais. Sobre esse ponto, podemos destacar o papel do modelo das redes Booleanas, uma técnica matematicamente simples capaz de contribuir de forma substancial em estudos de regulação gênica. Neste capítulo, apresentaremos o paradigma das redes Booleanas, que utilizaremos na modelagem da canalização, assim como algumas de suas características e vantagens, bem como trabalhos recentes referentes ao modelo.

\subsection{Modelo de redes Booleanas}

Um modelo interessante por sua simplicidade no estudo de redes gênicas é o modelo de redes Booleanas, introduzido na biologia por Kauffman [23]. Nesse modelo, as expressões gênicas são representadas por apenas dois valores: "ligado" ou "desligado". O nível de expressão ("ligado" ou "desligado") de cada gene é funcionalmente relacionado aos níveis de expressão de outros genes através de funções Booleanas. Esse modelo é completamente determinístico.

Uma rede Booleana, ou BN (Boolean Network), $B=(V, f)$, com $n$ genes é definida por um conjunto de variáveis $V=\left\{x_{1}, x_{2}, \ldots, x_{n}\right\}, x_{i} \in\{0,1\}, i=1, \ldots, n$, e um vetor de funções Booleanas $\boldsymbol{f}=\left(f_{1}, f_{2}, \ldots, f_{n}\right)$, $f_{i}:\{0,1\}^{n} \rightarrow\{0,1\}, i=1, \ldots, n$. Cada $x_{i}$ é uma variável que representa o estado/expressão do gene $i$, onde $x_{i}=1$ representa que o gene $x_{i}$ está expresso e $x_{i}=0$ significa que o gene $x_{i}$ não está expresso.

A função $f_{i}$ é chamada de função preditora do gene $x_{i}$. O vetor das funções Booleanas $f$ representa as regras das interações regulatórias entre os genes. Neste trabalho, consideramos que a atualização dos estados de todos os genes é feita de forma sincronizada em todo instante de tempo segundo as funções preditoras, ou seja, o valor de cada variável $x_{i}$ é completamente determinado no tempo $t+1$ pelos valores das outras variáveis no tempo $t$, usando a função Booleana $f_{i}$ de $\boldsymbol{f}$ :

$$
x_{i}(t+1)=f_{i}\left(x_{1}(t), x_{2}(t), \ldots, x_{n}(t)\right) .
$$

Assim, em cada instante de tempo $t$, o vetor $s(t)$ formado pelos valores binários das $n$ variáveis da BN 
forma uma $n$-upla pertencente ao conjunto $\{0,1\}^{n}$. Definimos, dessa forma, o estado ou configuração de uma BN com $n$ variáveis no tempo $t$ como sendo o vetor $s(t) \in\{0,1\}^{n}$. Uma BN com $n$ genes possui $2^{n}$ estados possíveis.

Dada uma rede Booleana $B=(V, \boldsymbol{f})$ com $n$ genes, o vetor de funções Booleanas $\boldsymbol{f}=\left(f_{1}, \ldots, f_{n}\right)$ pode representar uma função de transição $\boldsymbol{f}:\{0,1\}^{n} \rightarrow\{0,1\}^{n}$, de forma que $s(t+1)=\boldsymbol{f}(s(t))$, ou seja, o valor do gene $i$ no estado $s(t+1)$ é obtido pela aplicação $f_{i}(s(t))$. O vetor $\mathbf{f}=\left(f_{1}, \ldots, f_{n}\right)$ é chamado de $f u n c ̧ a \tilde{o}$ de transição ou função de rede.

O diagrama de transição de estados de uma rede Booleana $B=(V, f)$ com $n$ genes é um grafo dirigido $G_{B}=\left(V_{B}, A_{B}\right)$, em que os vértices são todos os estados possíveis da rede, isto é, $V_{B}=\{0,1\}^{n}$, e existe um arco de $s_{k} \in V_{B}$ para $s_{l} \in V_{B}$ (isto é, $\left(s_{k}, s_{l}\right) \in A_{B}$ ), se, e somente se, $s_{l}=\boldsymbol{f}\left(s_{k}\right)$. Um exemplo de diagrama de transição de estados pode ser encontrado na Figura 3.2.

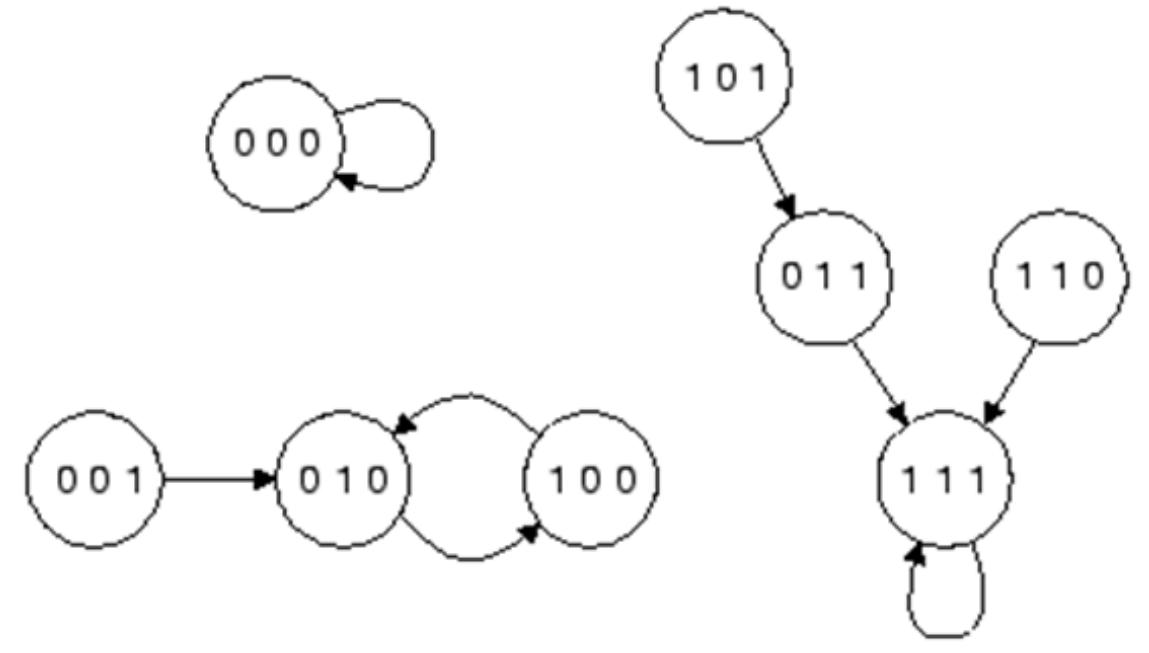

Figura 3.1: Diagrama de transição de estados de uma rede Booleana com 3 genes.

Uma vez que o número de estados de uma BN é finito e que a rede sempre transita de um estado para outro, é fácil ver que depois de o sistema iterar por um determinado tempo, certos estados serão revisitados de uma maneira cíclica. Tais estados formam o que chamamos de atratores.

Um atrator é um ciclo dirigido no diagrama de transição de estados da BN. Dado um atrator, o conjunto de todos os estados que conduzem a este atrator é chamado de bacia de atração. As bacias formam uma partição no diagrama de estados de uma BN. Os estados que não estão nos atratores são chamados de estados transientes e eles são visitados somente uma única vez em qualquer trajetória de transição de estados de uma BN. Um exemplo de bacia de atração e atrator pode ser encontrado na Figura ??.

\subsubsection{Redes Booleanas com pertubação}

Semelhantemente a uma rede Booleana, uma rede Booleana com pertubação é uma variação estocástica da anterior.

Nesse modelo, o valor do gene $i$ no estado $s(t+1)$ é obtido pela aplicação $f_{i}(s(t))$, seguida de uma pertubação aleatória de probabilidade $p$, tipicamente pequena. Cada gene, então, terá seu valor definido, na maioria dos casos, por sua função de transição e, nos demais, aleatoriamente.

Se considerarmos o diagrama de transição de estados como uma cadeia de Markov, o diagrama de uma rede Booleana com pertubação pode ser relacionado com uma cadeia de Markov ergódica quase determinística, 


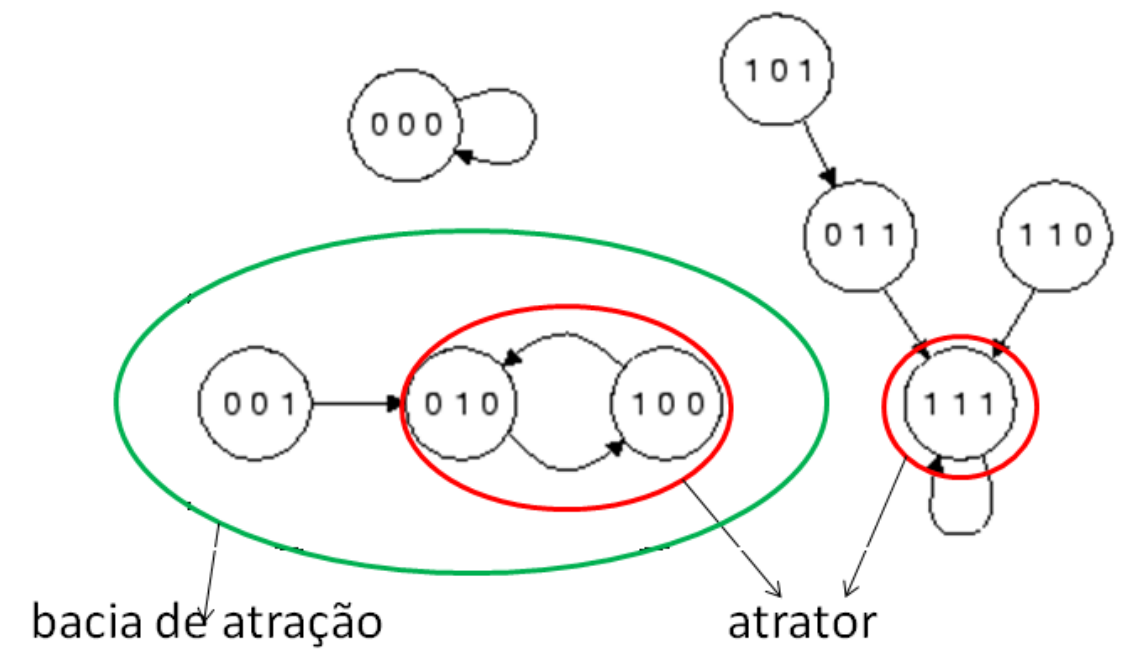

Figura 3.2: Bacias de atração e atratores de uma rede Booleana com 3 genes.

se considerarmos $p \cong 0$.

Nas análises realizadas neste trabalho, não utilizamos redes Booleana com pertubação. Redes determinísticas foram escolhidas por serem mais simples de serem implementadas e ainda apresentarem resultados passíveis de interpretação biológica, como amplamente analisado nos trabalhos de Kauffman [23].

\subsubsection{Redes Booleanas sensíveis ao contexto}

Uma generalização do modelo de redes Booleanas é o modelo de redes Booleanas sensíveis ao contexto, que pode ser utilizado por sua capacidade de modelar diferentes cenários de um organismo.

Uma rede Booleana sensível ao contexto é composta por uma coleção finita de redes Booleanas (BNs) $B_{1}=\left(V, \boldsymbol{f}_{1}\right), B_{2}=\left(V, \boldsymbol{f}_{2}\right), \ldots, B_{k}=\left(V, \boldsymbol{f}_{k}\right)$.

Assim como no modelo de redes Booleanas, o cálculo de cada $s(t+1)$ é dado pela função $\boldsymbol{f}_{j}$ de uma das BNs da coleção. Nesse modelo, uma BN $B_{i}$ permanece fixa por um determinado intervalo de tempo, até a ocorrência de um evento aleatório (um estímulo externo, por exemplo), que troca o sistema por uma outra $\mathrm{BN} B_{j}$. A troca de uma BN por outra corresponde a uma troca do diagrama de estados do sistema.

Tendo em vista que esta troca de BNs corresponde a uma mudança de contexto no sistema, esse modelo está cada vez mais sendo estudado [6,7,38,64], talvez devido ao seu poder de modelar várias redes BNs conjuntamente e por melhor explicar dados biológicos.

\subsubsection{Redes Booleanas com limiar}

O modelo de redes Booleanas com limiar (em inglês, threshold Boolean network, ou simplesmente TBN) é um derivado do modelo de redes Booleanas que considera apenas um determinado subconjunto de funções Booleanas como possíveis funções de transição.

Em uma TBN, consideramos que a relação entre dois genes deve ser descrita como um dos três seguintes tipos: regulação positiva, regulação negativa ou nenhuma interação.

Na construção de uma TBN, as relações regulatórias entre os genes são descritas em uma matriz $A_{n \times n}$, usando a seguinte convenção: $a_{i j}>0$ para uma regulação positiva do gene $x_{j}$ no gene $x_{i}, a_{i j}<0$ para uma regulação negativa do gene $x_{j}$ no gene $x_{i}$ e $a_{i j}=0$ para nenhuma interação entre os genes.

A função booleana $f_{i}$ é definida de acordo com a matriz $A$, um valor de limiar $\theta$ e os valores dos genes 
no tempo $t$ :

$$
x_{i}(t+1)= \begin{cases}1, & \text { se } \sum_{j \leq n} a_{i j} x_{j}(t)>\theta \\ 0, & \text { se } \sum_{j \leq n} a_{i j} x_{j}(t)<\theta \\ x_{i}(t), & \text { se } \sum_{j \leq n} a_{i j} x_{j}(t)=\theta .\end{cases}
$$

O somatório $\sum_{j} a_{i j} x_{j}(t)$ é chamado de input do gene $x_{i}$ no instante de tempo $t$. Biologicamente, uma relação de autodegradação ou autopromoção seria modelada pelo valor de $a_{i i}$.

Podemos fazer duas considerações sobre as vantagens do modelo de redes Booleanas com limiar:

- Proximidade com a nomenclatura biológica. Ao descrever as relações dos genes como inibição ou promoção, uma TBN pode facilitar o diálogo necessário à construção do modelo.

- Simplificação das interações gênicas. Em muitos mecanismos moleculares, as relações entre os genes podem obedecer complexos sistemas de regulação, como o Operon Lac. Entretanto, os tipos de dados necessários para a inferência de sistemas complexos de interação, como os baseados em equações diferenciais, são de difícil obtenção. Uma TBN considera esses sistemas uma sobreposição de relações mais simples, simplificando a descrição e, como veremos, a manipulação.

Entre outras vantagens, o modelo de TBN já produziu resultados interessantes. Modelando as relações entre os genes da levedura, Li.et al. [33] modelou o ciclo celular da levedura. Zhang et. al. [66] obteve resultados semelhantes usando TBN estocásticas - semelhantes às redes Booleanas com pertubação da seção 3.1.1. Em trabalhos anteriores [15], exibimos um método em que, a partir de dados temporais de microarray binarizados, é possível extrair informações sobre as relações entre os genes, seguindo o modelo de TBN.

\subsection{Redes Booleanas na literatura}

Desde o artigo de Kauffman [23], de 1969, muitas vezes considerado o trabalho seminal da utilização de redes Booleanas em sistemas biológicos, muito tem sido estudado sobre redes Booleanas em Biologia.

Em seu livro The Origins of Order [25], Kauffman reúne os principais estudos sobre caracterização de redes Booleanas: quantidade de atratores, tamanho dos atratores, funções booleanas e muitas interpretações sobre o papel desses conceitos na Biologia. Essa obra condensa grande parte do conhecimento sobre redes Booleanas e deve ser consultada como referência para qualquer trabalho sobre o tema.

Além desse livro, dois reviews muito bons e completos podem ser encontrados no trabalhos de Bornholdt [3] e Xiao [63].

Analisando os mais recentes trabalhos em redes Booleanas, além de percebermos que esse ainda é um tema relevante para a Biologia, é possível identificar algumas tendências. Nos últimos cinco anos, cerca de 50 trabalhos sobre redes Booleanas foram indexados pelo PubMed ${ }^{1}$. Desses, pelo menos dez trataram de redes Booleanas probabilísticas, cinco trataram da interação entre redes Booleanas e sistemas complexos, quatro trataram da importância da bacia de atração de uma rede Booleana em redes de regulação gênica, sete trataram de controle em redes Booleanas e muitos outros estudaram aspectos da dinâmica e da aplicações de redes Booleanas em sistemas biológicos.

\footnotetext{
${ }^{1}$ PubMed: http://www.ncbi.nlm.nih.gov/pubmed/
} 
Em geral, a maioria dos trabalhos valida a utilização de redes Booleanas na modelagem de sistemas biológicos, seja mostrando redes Booleanas que descrevem importantes redes de regulação gênica, seja apresentando características teóricas úteis para a compreensão de redes na Biologia.

Abaixo, listamos as tendências, encontradas na literatura, mais relevantes para este trabalho e as contribuições de alguns autores nesses tópicos.

\subsubsection{Trabalhos sobre a estabilidade de redes Booleanas}

A estabilidade foi um tema recorrente em publicações sobre redes Booleanas nos últimos anos. Como citado na Introdução deste trabalho, a estabilidade é tratada de diversas formas: percolação ${ }^{2}$ [46, 48], entropia [32] e estabilidade na pertubação de estados [39,65].

É interessante notar que alguns trabalhos se referem à bacia de atração de uma rede como uma característica relacionada à estabilidade. Krawitz et. al [32] introduz uma medida de entropia na bacia de atração de uma BN. Esmaeili et. al [10] utiliza o tamanho de uma bacia de atração em um processo de seleção de redes Booleanas, simulando a evolução.

Os trabalhos de Willadsen et. al [61] e Boldhaus et. al [2] procuram relacionar o tamanho da bacia de atração com conceitos biológicos. Willadsen investiga o tamanho da bacia de atração de duas redes Booleanas com inspiração biológica: a rede de polaridade segmentada da Drosophila melanogaster e a rede do ciclo celular da Saccharomyces cerevisiae. Já o trabalho de Boldhaus estuda o efeito da remoção de um nó no tamanho da bacia de atração de uma rede Booleana, em uma abordagem semelhante à desenvolvida no Capítulo 5.

\subsubsection{Trabalhos sobre controle de redes Booleanas}

Estudos sobre estratégias de controle em redes Booleanas têm despertado o interesse da comunidade científica particularmente nos últimos dois anos. Essa linha de pesquisa em redes Booleanas foca na resposta à seguinte pergunta: Como evitar que a rede Booleana entre em equilíbrio em determinados estados associados a fenótipos indesejáveis?

Em geral, a busca de estratégias de controle é feita em variações estocásticas de redes Booleanas [19,31,58]. O trabalho de Hayashida et. al [14] trata de estratégias de controle para facilitar a indução de atratores de tamanho unitário em uma rede Booleana.

\footnotetext{
${ }^{2}$ Teoria matemática que estuda a propagação em superfícies formadas pela junção de diversos componentes (grids, lattices e outros). Em www.esse.ou.edu/glossary_st.html.
} 


\section{Capítulo 4}

\section{Funções Booleanas}

O conjunto de funções Booleanas é um componente essencial de uma rede. A escolha da classe de função Booleana de uma rede pode alterar significativamente sua dinâmica e sua interpretação biológica.

Para ilustrar essa importância, este capítulo contém a definição, as características e exemplos de alguns conjuntos de funções que apresentam, na literatura, relações com a estabilidade de redes de regulação e, consequentemente, com a canalização de características. Ao final, realizamos uma pequena discussão sobre o uso de diferentes conjuntos de funções Booleanas em redes de regulação.

\subsection{Tabela verdade}

Uma tabela verdade representa graficamente uma função Booleana. Cada linha de uma tabela verdade exibe a saída da função (coluna mais à direita) a partir de suas variáveis (demais colunas).

\begin{tabular}{ccc|c}
$x_{1}$ & $x_{2}$ & $x_{3}$ & $f\left(x_{1}, x_{2}, x_{3}\right)$ \\
\hline 0 & 0 & 0 & 1 \\
0 & 0 & 1 & 0 \\
0 & 1 & 0 & 1 \\
0 & 1 & 1 & 0 \\
1 & 0 & 0 & 1 \\
1 & 0 & 1 & 1 \\
1 & 1 & 0 & 1 \\
1 & 1 & 1 & 0
\end{tabular}

Tabela 4.1: Um exemplo de tabela verdade de três variáveis. As variáveis $x_{1}, x_{2}$ e $x_{3}$ são preditores da função $f\left(x_{1}, x_{2}, x_{3}\right)$.

As dimensões de uma tabela verdade dependem da quantidade de variáveis. Uma função de $k$ variáveis é representada por uma tabela de $k+1$ colunas e $2^{k}$ linhas. Variando todas as possíveis saídas de todas as linhas de uma tabela verdade, calculamos a quantidade total de funções Booleanas de $k$ variáveis: $2^{2^{k}}$.

A partir da tabela verdade, alguns conjuntos de funções a serem definidas neste capítulo são mais fáceis de serem compreendidos.

\subsection{Conjunto de funções Canalizadoras}

Uma das primeiras formas de se tratar a canalização sob o ponto de vista computacional foi introduzida por Kauffman em 1971 [24], através do conceito de função Booleana canalizadora.

Uma função Booleana canalizadora é uma função Booleana completamente determinada por uma de suas variáveis. Em outras palavras: 
Definição Seja $f$ uma função Booleana de $k$ preditores. A função $f$ pertence ao conjunto de funções canalizadoras com valor canalizador $a$, gene canalizador em $x_{i}$ e com saída canalizada $b$, se $x_{i}=a \Rightarrow$ $f\left(x_{1}, \ldots, x_{i}, \ldots, x_{k}\right)=b$, com $a, b \in\{0,1\}$.

Intuitivamente, se $f$ é uma função canalizadora, seu valor é completamente determinado por um de seus genes preditores, o gene canalizador.

Na Tabela 4.2, encontramos um exemplo de função canalizadora cuja variável canalizadora é $x_{1}$.

\begin{tabular}{|c|c|c|c|}
\hline \multicolumn{5}{|c|}{ Exemplo de função canalizadora } \\
\hline$x_{1}$ & $x_{2}$ & $x_{3}$ & $f\left(x_{1}, x_{2}, x_{3}\right)$ \\
\hline 0 & 0 & 0 & 0 \\
\hline 0 & 0 & 1 & 1 \\
\hline 0 & 1 & 0 & 1 \\
\hline 0 & 1 & 1 & 0 \\
\hline 1 & 0 & 0 & 1 \\
\hline 1 & 0 & 1 & 1 \\
\hline 1 & 1 & 0 & 1 \\
\hline 1 & 1 & 1 & 1 \\
\hline
\end{tabular}

Tabela 4.2: Tabela verdade para a função $f$ e seus preditores. Nesse exemplo, temos que $x_{1}=1 \Rightarrow f\left(x_{1}, x_{2}, x_{3}\right)=1$. Logo, $x_{1}$ é um gene canalizador e $f\left(x_{1}, x_{2}, x_{3}\right)$ é uma função canalizadora.

As primeiras referências às funções canalizadoras as tratam como funções de estruturas forçadas ${ }^{1}$. O trabalho de 1971 de Kauffaman [24] lista diversas características de redes de regulação construídas a partir dessas funções. Em seu livro The Origins of Order [25], Kauffman deixa claro o porquê da mudança de nomenclatura:

"The term 'Canalyzing' was chosen to honor the fine biologist C.H.Waddington, who liked to think about such things with respect to entire epigenetic landscapes".

Atualmente, muitos trabalhos tratam de funções Booleanas canalizadoras, principalmente sobre características de redes construídas a partir dessas funções [26, 27,37].

Podemos relacionar funções canalizadoras e canalização de características. Um gene submetido a uma função canalizadora depende de apenas outro gene; portanto, seu estado é estável em relação a modificações em seus outros preditores. Se construirmos uma rede de regulação com muitos genes canalizados, a própria rede torna-se estável em relação a modificações. Ao associarmos o funcionamento de uma rede de regulação com um fenótipo, podemos considerar a presença de funções canalizadoras como a base para a canalização de características.

Como podemos perceber, as funções canalizadoras apresentam uma abordagem bottom-up para a modelagem da canalização ao relacionar genes a fenótipos.

\subsection{Conjunto de funções canalizadoras aninhadas}

A definição de função Booleana canalizadora aninhada - do inglês Nested Canalizing function - é uma extensão recursiva do conceito de função canalizadora [20,26]. Assim, como uma função canalizadora, uma função canalizadora aninhada tem sua saída controlada por um gene canalizador. Entretanto, quando seu gene canalizador não possuiu seu valor canalizador, outro gene é responsável pela canalização da função e assim subsequentemente.

\footnotetext{
${ }^{1}$ Em inglês: forcing structures functions
} 
Definição Seja $f$ uma função Booleana de $k$ variáveis e $\sigma$ uma permutação em $\{1, \ldots, k\}$. A função $f$ pertence ao conjunto de funções canalizadoras aninhadas na ordem de variáveis $x_{\sigma(1)}, \ldots, x_{\sigma(k)}$, com valores canalizadores $a_{1}, \ldots, a_{k}$ e com saídas canalizadas $b_{1}, \ldots, b_{n}$, respectivamente, se:

$$
f\left(x_{1}, \ldots, x_{k}\right)=\left\{\begin{array}{l}
b_{1}, \text { se } x_{\sigma(1)}=a_{1} \\
b_{2}, \text { se } x_{\sigma(1)} \neq a_{1} \text { and } x_{\sigma(2)}=a_{2} \\
b_{3}, \text { se } x_{\sigma(1)} \neq a_{1} \text { and } x_{\sigma(2)} \neq a_{2} \text { and } x_{\sigma(3)}=a_{3} \\
\ldots \\
b_{k}, \text { se } x_{\sigma(1)} \neq a_{1} \text { and } \ldots \text { and } x_{\sigma(k)}=a_{k}
\end{array}\right.
$$

\subsection{Conjunto de funções IMP determinísticas}

O conceito de Predição Intrinsecamente Multivariada (em inglês, Intriscically Multivariate Prediction, IMP) foi introduzido por Martins et. al [35] como um modelo para genes canalizadores, ou simplesmente genes que apresentam amplas funções regulatórias no organismo em determinados contextos, mas que, em geral, não apresentam influência sobre seus alvos.

Em seu trabalho, Martins define IMP no âmbito de funções Booleanas e diferentes probabilidades para os preditores. Essa definição, no entanto, pode ser facilmente estendida para o caso determinístico, embora a interpretação biológica da classe seja prejudicada.

Para definir matematicamente a classe de funções Booleanas IMP determinísticas, é necessário antes definirmos erro padrão e erro de predição.

O erro padrão de uma função Booleana representa o erro cometido na predição da saída da função caso nenhuma informação sobre suas variáveis esteja disponível.

Definição Seja $f$ uma função Booleana de $k$ variáveis, $X_{k}=\{0,1\}^{k}$ o conjunto de valores possíveis das $k$ variáveis e $T(v)=\sum_{\forall x \in X_{k}} I[f(x)=v]$, em que $I[p]$ vale 1 se $p$ é uma expressão verdadeira e 0 caso contrário. O erro padrão $E_{0}$ de $f$ é dado por:

$$
E_{0}=\frac{\min \{T(1), T(0)\}}{2^{k}}
$$

O erro de predição de uma função é definido a partir de um subconjunto $Z \subseteq\left\{x_{1}, x_{2}, \ldots, x_{k}\right\}$. Sem perda de generalidade, considere $Z=\left\{x_{1}, x_{2}, \ldots, x_{\ell}\right\}$ with $\ell \leq k$. O cálculo desse erro, $E_{Z}(f)$, é uma forma estendida do erro padrão da função, e pode ser definido como:

$$
E_{Z}(f)=\sum_{\left(x_{1}, x_{2}, \ldots, x_{\ell}\right) \in\{0,1\}^{\ell}} \min \left\{H\left(x_{1}, x_{2}, \ldots, x_{\ell}, 0\right), H\left(x_{1}, x_{2}, \ldots, x_{\ell}, 1\right)\right\}
$$

em que

$$
H\left(x_{1}, x_{2}, \ldots, x_{\ell}, v\right)=\sum_{\left.\left(a_{1}, \ldots, a_{k-\ell}\right) \in\{0,1\}\right\}^{k-\ell}} I_{\left[f\left(x_{1}, x_{2}, \ldots, x_{\ell}, a_{1}, \ldots, a_{k-\ell}\right)=v\right]} .
$$

Com isto, a definição de conjunto IMP determinístico segue.

Definição Seja $f$ uma função Booleana de $k$ preditores $P=\left\{x_{1}, x_{2}, \ldots, x_{k}\right\}$. A função $f$ é IMP determinística se, para todos os subconjuntos $Q$ de $P, E_{Q}(f)=E_{0}(f)$. 
Esta definição fica clara com um exemplo. Considere a função de três variáveis presente na tabela verdade 4.3. Vamos calcular o erro padrão do subconjunto em que somente as variáveis $x_{1}$ e $x_{3}$ são consideradas, chamado de $E_{x_{1}, x_{3}}$.

\begin{tabular}{|c|c|c|c|}
\hline$x_{1}$ & $x_{2}$ & $x_{3}$ & $f\left(x_{1}, x_{2}, x_{3}\right)$ \\
\hline 0 & 0 & 0 & 0 \\
\hline 0 & 0 & 1 & 0 \\
\hline 0 & 1 & 0 & 1 \\
\hline 0 & 1 & 1 & 0 \\
\hline 1 & 0 & 0 & 1 \\
\hline 1 & 0 & 1 & 1 \\
\hline 1 & 1 & 0 & 0 \\
\hline 1 & 1 & 1 & 1 \\
\hline
\end{tabular}

Tabela 4.3: Tabela verdade para a função $f$.

Para o cálculo de $E_{x_{1}, x_{3}}$, a Tabela 4.3 é modificada da seguinte forma: a coluna referente a $x_{2}$ é eliminada e as linhas com variáveis repetidas são sumarizadas nas colunas $f\left(x_{1}, x_{3}\right)=0$ e $f\left(x_{1}, x_{3}\right)=1$. O resultado encontra-se na Tabela 4.4.

\begin{tabular}{|c|c|c|c|}
\hline$x_{1}$ & $x_{3}$ & $f\left(x_{1}, x_{3}\right)=0$ & $f\left(x_{1}, x_{3}\right)=1$ \\
\hline 0 & 0 & 1 & 1 \\
\hline 0 & 1 & 2 & 0 \\
\hline 1 & 0 & 1 & 1 \\
\hline 1 & 1 & 0 & 2 \\
\hline
\end{tabular}

Tabela 4.4: Tabela verdade sumarizada da função $f$.

O menor valor entre as colunas $f\left(x_{1}, x_{3}\right)=0$ e $f\left(x_{1}, x_{3}\right)=1$ na Tabela 4.4 define o erro de predição para cada possível valor de $x_{1}$ e $x_{3}$. Esse valor é representado na coluna "Erro" da Tabela 4.5.

\begin{tabular}{|c|c|c|c|c|}
\hline$x_{1}$ & $x_{3}$ & $f\left(x_{1}, x_{3}\right)=0$ & $f\left(x_{1}, x_{3}\right)=1$ & Erro \\
\hline 0 & 0 & 1 & 1 & 1 \\
\hline 0 & 1 & 2 & 0 & 0 \\
\hline 1 & 0 & 1 & 1 & 1 \\
\hline 1 & 1 & 0 & 2 & 0 \\
\hline \hline & & & Soma & 2 \\
\hline
\end{tabular}

Tabela 4.5: Tabela verdade para a função $f$ com a coluna Erro, que representa o erro cometido por cada linha da tabela verdade sumarizada.

A soma da coluna "Erro" da Tabela 4.5, ponderada pela quantidade total de possíveis valores das variáveis da função, representa o erro de predição de $f$ em relação a $x_{1}$ e $x_{3}$ :

$$
E_{x_{1}, x_{3}}=\frac{2}{2^{3}}
$$

O procedimento de cálculo de $E_{x_{1}, x_{3}}$ pode ser facilmente generalizado para o erro de todos os subconjuntos de variáveis da função. No limite, esse procedimento realizado sem nenhuma variável calcula o erro padrão $E_{0}$. Além disso, $E_{x_{1}, x_{2}, x_{3}}=0$. 
Intuitivamente, uma função Booleana IMP determinística pode ser apenas predita se todas as suas variáveis forem observadas. Por sua ligação com a estabilidade de redes, essa generalização determinística dos genes IMP é analisada neste trabalho.

\subsection{Classe de funções Post}

As funções Booleanas da Classe Post são conhecidas desde 1922, quando o matemático Emil Post caracterizou todas as funções Booleanas fechadas através de composição [41,42]. A definição de função Booleana fechada por composição é apresentada abaixo.

Definição Seja $A$ um conjunto de funções Booleanas. A função Booleana $f \in A$ é fechada por composição se $f \circ f \in A$.

Recentemente, Shmulevich et. al [52] relacionou funções Booleanas da Classe Post com a estabilidade de redes e a canalização. Por esse motivo, esse conjunto de funções é analisado neste trabalho.

Dentro do conjunto de funções Booleanas Post, trabalhamos com dois subconjuntos estudados no trabalho de Shmulevich: as classes $A^{\infty}-a^{\infty}$ e $A^{2}-a^{2}$. Redes construídas a partir dessas classes demonstraram bons resultados em estabilidade e ordem.

\subsubsection{Classe de funções $A^{\infty}-a^{\infty}$}

A classe de funções $A^{\infty}-a^{\infty}$, também chamada aqui de classe Post-infinito, é composta pela união dos conjuntos $A^{\infty}$ e $a^{\infty}$. A definição de $A^{\infty}$ segue:

Definição Uma função Booleana $f$ pertence à classe $A^{\infty}$ se todas as linhas da tabela verdade de $f$, na qual a função tem saída 1, possuem uma variável semelhante valendo 1.

Para $a^{\infty}$, basta substituir 1 por 0 na definição acima.

A função Booleana representada na Tabela Verdade 4.6 é da classe $A^{\infty}$. Para todas as linhas em que a função tem saída 1 , a variável $x_{2}$ vale 1 .

\begin{tabular}{|c|c|c|c|}
\hline$x_{1}$ & $x_{2}$ & $x_{3}$ & $f\left(x_{1}, x_{2}, x_{3}\right)$ \\
\hline 0 & 0 & 0 & 0 \\
\hline 0 & 0 & 1 & 0 \\
\hline 0 & 1 & 0 & 1 \\
\hline 0 & 1 & 1 & 1 \\
\hline 1 & 0 & 0 & 0 \\
\hline 1 & 0 & 1 & 0 \\
\hline 1 & 1 & 0 & 1 \\
\hline 1 & 1 & 1 & 1 \\
\hline
\end{tabular}

Tabela 4.6: Tabela verdade para a função $f$, da classe $A^{\infty}$.

\subsubsection{Classe de funções Post $A^{2}-a^{2}$.}

A classe de funções $A^{2}-a^{2}$, também chamadas aqui de classe Post-2, é composta pela união dos conjuntos $A^{2}$ e $a^{2}$. A definição de $A^{2}$ segue:

Definição Uma função Booleana $f$ pertence à classe $A^{2}$ se todas os pares de linhas da Tabela Verdade de $f$, na qual a função tem saída 1, possuem uma variável semelhante valendo 1. Algumas linhas podem ser repetidas. 
Para $a^{2}$, basta substituir 1 por 0 na definição acima.

A função Booleana representada na Tabela Verdade 4.7 é da classe $A^{2}$. Para as linhas 4 e 7 , a variável $x_{2}$ vale 1 ; para as linhas 4 e 8 , a variável $x_{3}$ vale 1 e para as linhas 7 e 8 , a variável $x_{1}$ vale 1 .

\begin{tabular}{|c|c|c|c|}
\hline$x_{1}$ & $x_{2}$ & $x_{3}$ & $f\left(x_{1}, x_{2}, x_{3}\right)$ \\
\hline 0 & 0 & 0 & 0 \\
\hline 0 & 0 & 1 & 0 \\
\hline 0 & 1 & 0 & 0 \\
\hline 0 & 1 & 1 & 1 \\
\hline 1 & 0 & 0 & 0 \\
\hline 1 & 0 & 1 & 0 \\
\hline 1 & 1 & 0 & 1 \\
\hline 1 & 1 & 1 & 1 \\
\hline
\end{tabular}

Tabela 4.7: Tabela verdade para a função $f$, da classe $A^{2}$.

É fácil perceber que $A^{\infty} \subset A^{2}$.

\subsection{Conjunto de funções de limiar simplificada}

Na Seção 3.1.3, especificamos redes Booleanas construídas a partir de funções Booleanas com limiar. Seguimos agora com a definição do conjunto de funções de limiar.

Na construção de uma TBN, as relações regulatórias entre os genes são descritas em uma matriz $A_{n \times n}$, usando a seguinte convenção: $a_{i j}>0$ para uma regulação positiva do gene $x_{j}$ no gene $x_{i}, a_{i j}<0$ para uma regulação negativa do gene $x_{j}$ no gene $x_{i}$ e $a_{i j}=0$ para nenhuma interação entre os genes.

A função booleana $f_{i}$ é definida de acordo com a matriz $A$, um valor de limiar $\theta$ e os valores dos genes no tempo $t$ :

$$
x_{i}(t+1)= \begin{cases}1, & \text { se } \sum_{j \leq n} a_{i j} x_{j}(t)>\theta \\ 0, & \text { se } \sum_{j \leq n}^{j \leq n} a_{i j} x_{j}(t)<\theta \\ x_{i}(t), & \text { se } \sum_{j \leq n} a_{i j} x_{j}(t)=\theta .\end{cases}
$$

Neste trabalho, por simplicidade, utilizaremos apenas funções de limiar com parâmetros simplificados, a saber:

- $a_{i j}=1$, para regulação positiva entre os genes $i$ e $j$.

- $a_{i j}=-1$, para regulação negativa.

- $\theta=0$, no valor do limiar de todos os genes.

Apenas uma pequena quantidade de funções booleanas pode ser descrita através desse modelo, dados parâmetros simplificados. No conjunto de funções Booleanas de quatro variáveis, 16 das 65536 funções booleanas possíveis podem ser representadas por uma função Booleana de valores simplificados. Por esse motivo, muitas vezes esse modelo é chamado de "restrito" [15].

\subsection{Interseções entre conjuntos de funções Booleanas}

Os seis conjuntos de funções Booleanas apresentados não são mutualmente excludentes. Como exemplo, no trabalho de Shmulevich et. al [52], as interações entre classes Post são exibidas, ficando claro que $A^{n} \subset$ 


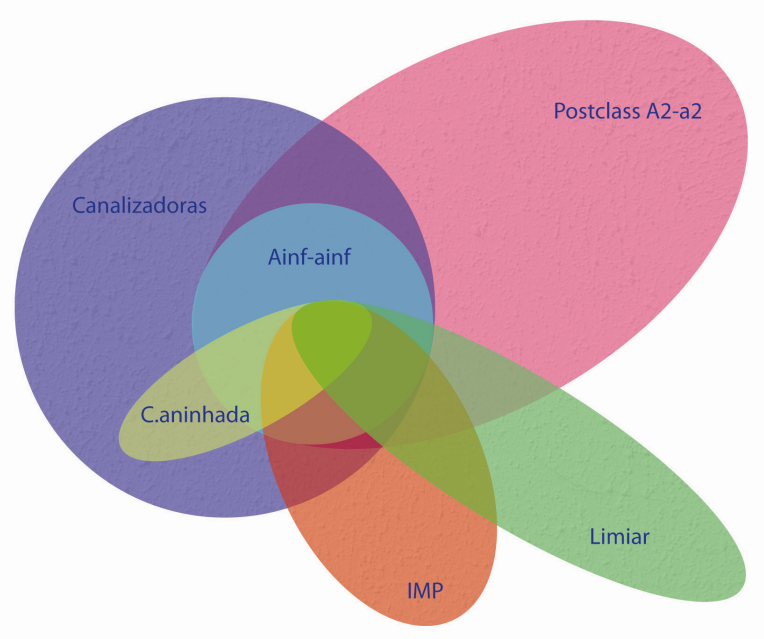

Figura 4.1: Diagrama de Venn para ilustrar as interseções entre funções Booleanas com $k=4$. O tamanho dos conjuntos segue (fracamente) uma escala proporcional à sua cardinalidade.

$A^{n+1}$. Além disso, por definição, as funções Booleanas canalizadoras aninhadas formam um subconjunto das funções Booleanas Canalizadoras.

Para o conjunto de funções de 4 variáveis, realizamos uma busca exaustiva no espaço total de funções Booleanas para verificar a cardinalidade dos conjuntos apresentados. Os resultados encontram-se na Tabela 4.8. Na Figura 4.1, exibimos um Diagrama de Venn com as interseções entre os conjuntos.

\begin{tabular}{|c|c|}
\hline Conjunto de funções & $\#$ \\
\hline Canalizadora & 3514 \\
\hline IMP & 1484 \\
\hline Limiar & 16 \\
\hline$A^{2}-a^{2}$ & 2740 \\
\hline C. Aninhada & 512 \\
\hline$A^{\infty}-a^{\infty}$ & 1880 \\
\hline
\end{tabular}

Tabela 4.8: Cardinalidade dos conjuntos de funções apresentadas

A partir das interseções apresentadas, realizamos análises nos conjuntos "Canalizadoras sem $A^{2}-a^{2}$ " e "IMP sem $A^{2}-a^{2}$ ". Esses subconjuntos ainda possuem uma cardinalidade razoável (1618 e 1206) e, como analisado na Seção 4.8, apresentam resultados interessantes.

\subsection{Medidas em redes de funções Booleanas}

Nesta seção estudamos as características de redes Booleanas construídas a partir das funções Booleanas apresentadas. Analisamos redes em que diferentes percentuais dos genes são regulados por funções de um determinado conjunto de funções Booleanas. Por simplicidade, todas as redes testadas contêm funções booleanas com uma quantidade $k$ de variáveis, o que nos permite tratar as redes Booleanas aqui estudadas por grafos de grau de entrada $k$.

Nessas redes, medimos: tamanho da maior bacia de atração, quantidade de atratores e quantidade de atratores de tamanho 1. Essas medidas foram escolhidas por, intuitivamente, apresentarem relações com 


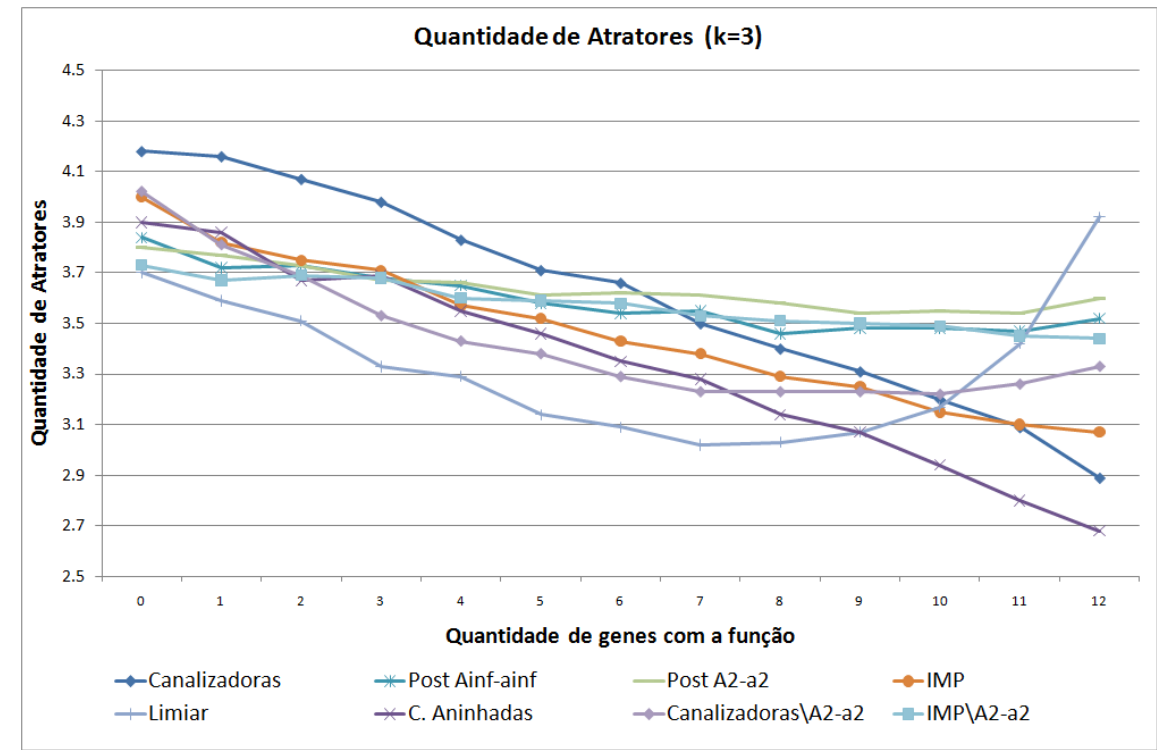

Figura 4.2: Quantidade de atratores para redes construídas a partir de diferentes funções Booleanas em que $k=3$.

a estabilidade da rede. No Capítulo 5, apresentamos razões para a medida "tamanho da maior Bacia de Atração" ser considerada uma boa medida de estabilidade.

Dois conjuntos de redes foram testadas: redes com 12 genes $(n=12)$ e 4 preditores (variáveis das funções Booleanas) $(k=4)$ e redes com 12 genes e 3 preditores $(k=3)$. Esses parâmetros foram escolhidos por representarem bem algumas redes gênicas modeladas como redes Booleanas e facilitarem as simulações computacionais. Cada gráfico apresentado contém os valores médios de 10.000 redes construídas aleatoriamente.

$\mathrm{Na}$ escolha das funções Booleanas de uma rede aleatória, uma quantidade $p$ de funções foi selecionada aleatoriamente de um conjunto determinado $C$ e a quantidade restante, $12-p$, escolhida do conjunto $U_{k}-C$, no qual $U_{k}$ representa o conjunto de universo de funções Booleanas de $k$ variáveis. O eixo horizontal de todas as figuras apresenta variações de $p$, de 0 a 12 .

$\mathrm{O}$ primeiro ponto de todos os gráficos, $p=0$, equivale às redes construídas sem preferência por um determinado conjunto de funções Booleanas. Nas redes em que $k=4$, podemos perceber que em $p=0$ todas as curvas possuem praticamente o mesmo valor, já que os conjuntos $U_{4}-C$ não são muito distintos, para todo $C$. Para $k=3$, é possível perceber variações das curvas em $p=0$, refletindo a alta cardinalidade dos conjuntos de funções Booleanas em relação ao conjunto universo $U_{3}$.

Medidas semelhantes para BNs em geral foram realizadas em The Origins of Order $^{2}$ [25] ou no próprio primeiro trabalho de Kauffman sobre BN [23].

\subsubsection{Quantidade de atratores}

Como aos atratores são atribuídos significados biológicos, é importante conhecermos a quantidade de atratores que uma rede Booleana construída a partir de diferentes funções possui.

Na Figura 4.3, analisamos a quantidade de atratores em diversas redes Booleanas construídas com diferentes funções. O eixo horizontal da figura representa a quantidade de genes cujas funções Booleanas pertencem a determinado conjunto, enquanto o eixo vertical equivale à média da quantidade de atratores encontrada.

\footnotetext{
${ }^{2}$ Um grande compêndio sobre redes Booleanas: resultados, análises, teorias e previsões
} 


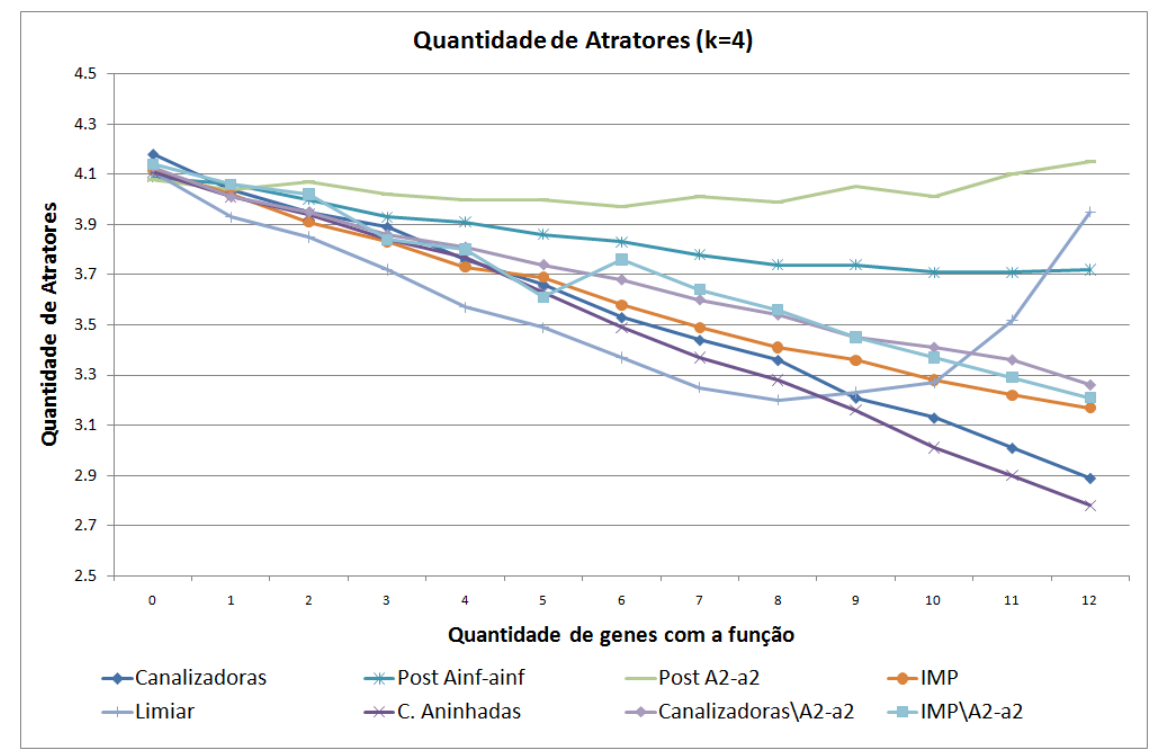

Figura 4.3: Quantidade de atratores para redes construídas a partir de diferentes funções Booleanas em que $k=4$.

\subsubsection{Quantidade de atratores de tamanho 1}

Um atrator de tamanho 1 representa um ponto fixo de um sistema dinâmico discreto. Em uma rede Booleana, uma dinâmica que atinge um atrator de tamanho 1 atingiu, intuitivamente, um ponto de equilíbrio do sistema, um estado que conduz a si próprio.

Em algumas ocasiões, é razoável esperar que o equilíbrio de uma célula seja representado pela exibição repetida de um mesmo padrão de expressão, no qual uma quantidade de genes apresenta-se ligada e outra quantidade, desligada. Em redes pequenas é razoável esperar esse comportamento, já que, invariavelmente, estímulos externos estarão envolvidos em sua atividade, especialmente os relacionados ao fim da estabilidade.

Nas Figuras 4.4 e 4.5, analisamos a quantidade de atratores de tamanho 1 em diversas redes Booleanas construídas com diferentes funções. O eixo horizontal da figura representa a quantidade de genes cujas funções Booleanas pertencem a determinado conjunto, enquanto o eixo vertical traz a quantidade média de atratores encontrada.

\subsubsection{Tamanho da maior bacia de atração}

A cada atrator está atribuída uma bacia de atração, correspondente aos estados transientes que conduzem o sistema àquele específico estado de equilíbrio. Por definição, todos os estados devem pertencer a uma, e somente uma, bacia de atração.

Neste tópico estamos interessados na quantidade de estados da maior bacia de atração. O tamanho de uma bacia de atração pode ser biologicamente interpretado como uma resistência do sistema a pertubações: se em um determinado estado $S_{t}$ a dinâmica sofrer uma pertubação e for conduzida aleatoriamente a outro estado $S_{t+1}$, a probabilidade de $S_{t}$ e $S_{t+1}$ pertencerem à mesma bacia $B_{i}$ e conduzirem ao mesmo atrator é diretamente proporcional ao tamanho da mesma. Ou seja:

$$
P\left(S_{t+1} \in B_{i} \mid S_{t} \in B i\right)=P\left(S_{t+1} \in B_{i}\right)=\frac{\operatorname{size}\left(B_{i}\right)}{2^{n}}
$$




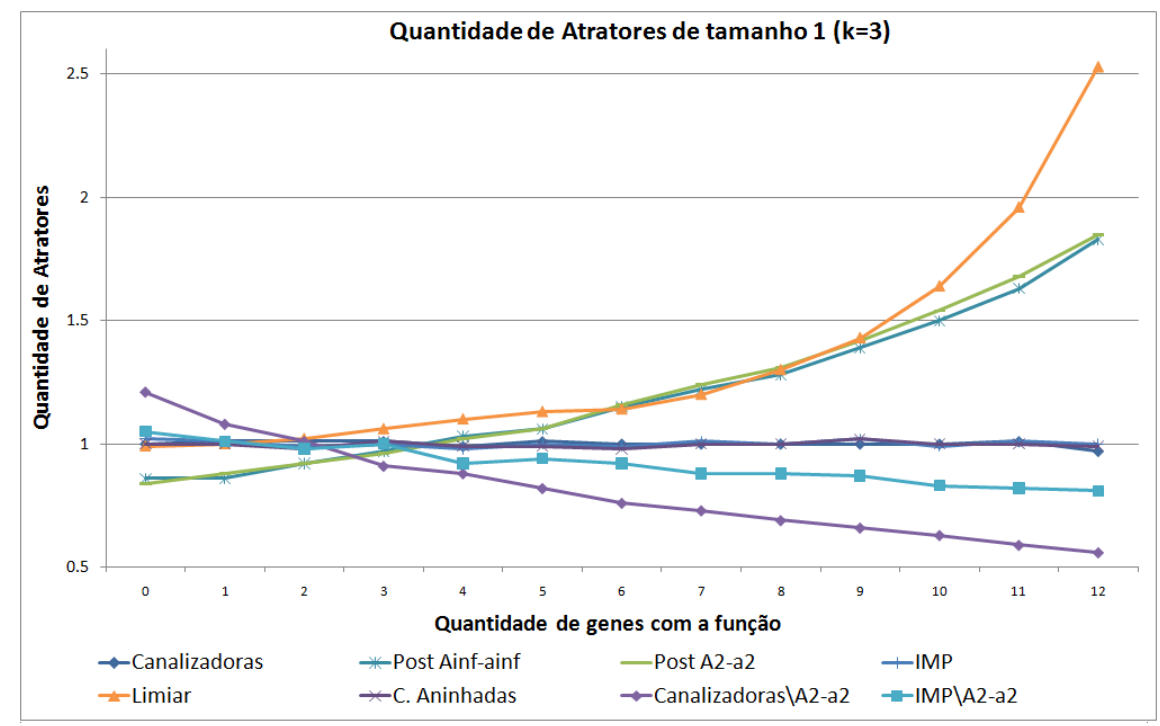

Figura 4.4: Quantidade de atratores de tamanho 1 para redes construídas a partir de diferentes funções Booleanas em que $k=3$.

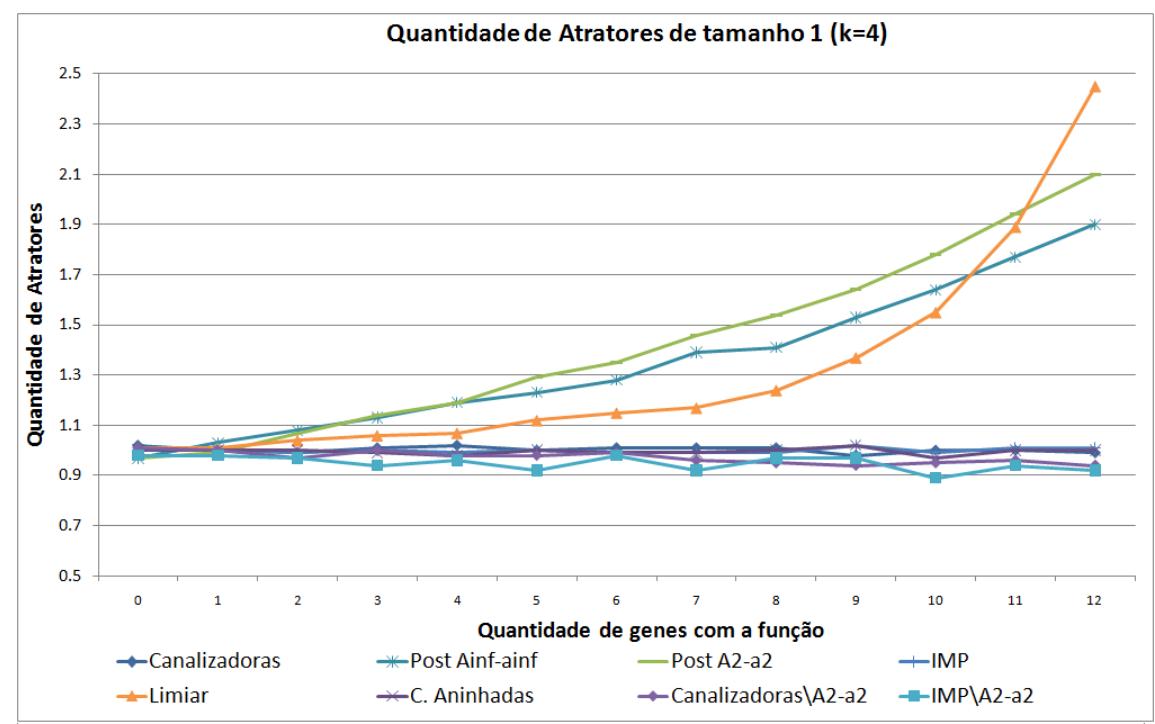

Figura 4.5: Quantidade de atratores de tamanho 1 para redes construídas a partir de diferentes funções Booleanas em que $k=4$.

Como um fenótipo canalizado representa, em um determinado ambiente, o fenótipo de maior sucesso, é possível considerar que ele possui a maior bacia de atração da rede, ou seja, essa característica continuará ativa para uma grande variedade de possibilidades de padrões de expressão gênica.

Podemos validar essa interpretação com a consideração de Waddington de que o Wild Type de um organismo é canalizado (Seção 2.2.1) e com o trabalho de Li et al. [33], no qual uma das evidências que apontam que a rede encontrada é relevante é o fato da bacia com significado biológico ser também a bacia de atração de maior tamanho.

Nas Figuras 4.6 e 4.7, analisamos o tamanho da maior bacia de atração em diversas redes Booleanas construídas com diferentes funções. O eixo horizontal da figura representa a quantidade de genes cujas 


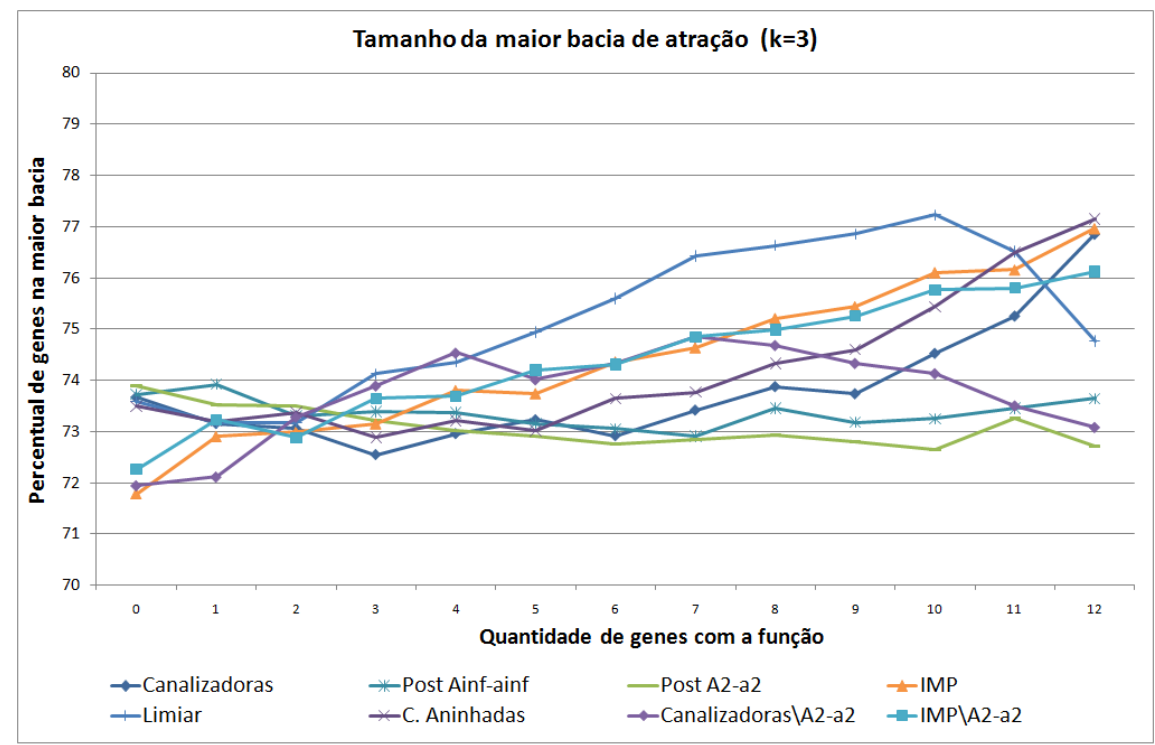

Figura 4.6: Tamanho da maior bacia de atração para redes construídas a partir de diferentes funções Booleanas em que $k=3$.

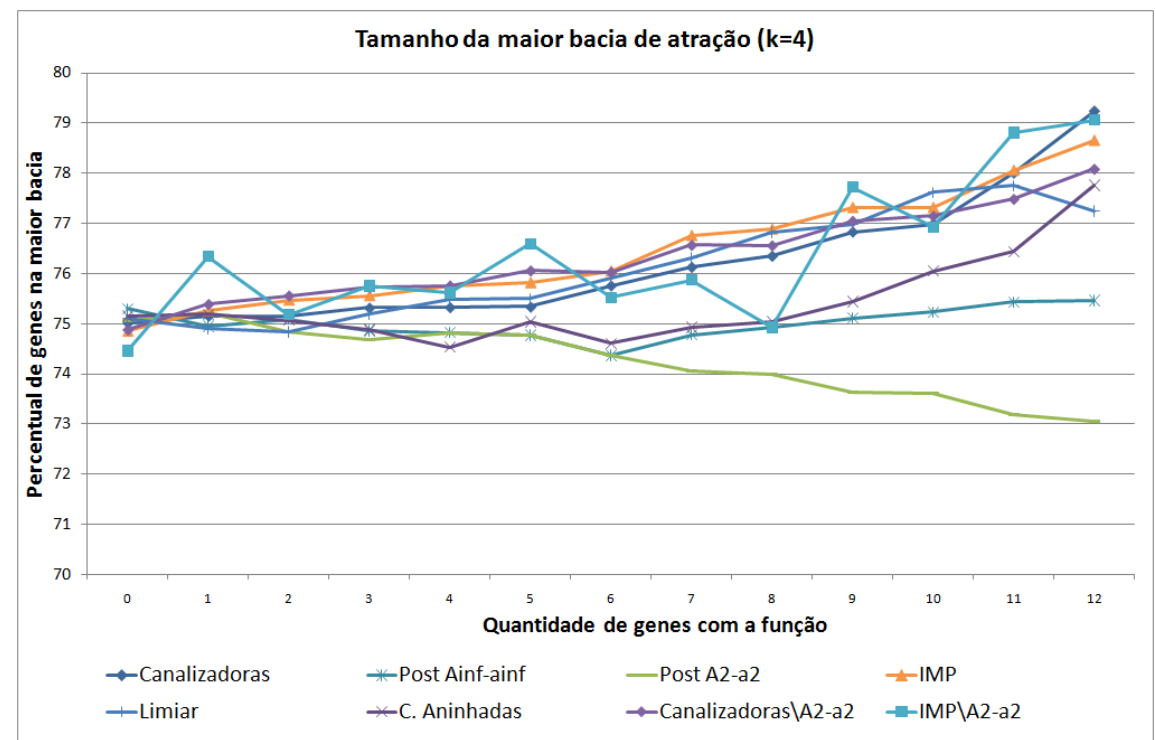

Figura 4.7: Tamanho da maior bacia de atração para redes construídas a partir de diferentes funções Booleanas em que $k=4$.

funções Booleanas pertencem a um determinado conjunto e o eixo vertical, a quantidade média de estados na maior bacia de atração dividida pela quantidade total de estados da rede, $2^{12}$.

Apenas para comparação, as Figuras 4.8 e 4.9 apresentam os resultados da análise para os conjuntos de funções Canalizadoras, $A^{2}-a^{2}$, IMP e "Canalizadoras sem $A^{2}-a^{2}$ ", "IMP sem $A^{2}-a^{2}$ ".

\subsection{Discussão}

As funções analisadas neste capítulo, com maior ou menor evidência, já foram relacionadas com estabilidade de rede na literatura. Além disso, as 3 medidas apresentadas também estão relacionadas com 


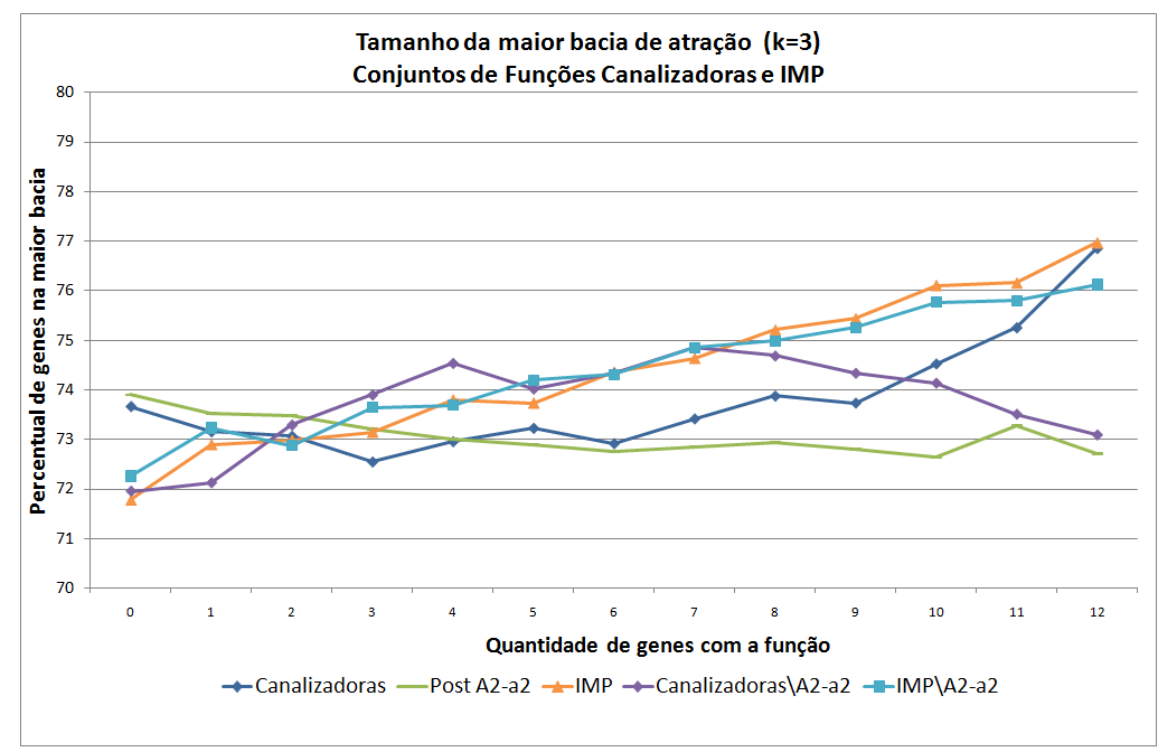

Figura 4.8: Tamanho da maior bacia de atração para redes construídas a partir de diferentes funções Booleanas em que $k=3$, gráfico dos conjuntos de funções Canalizadoras e IMP.

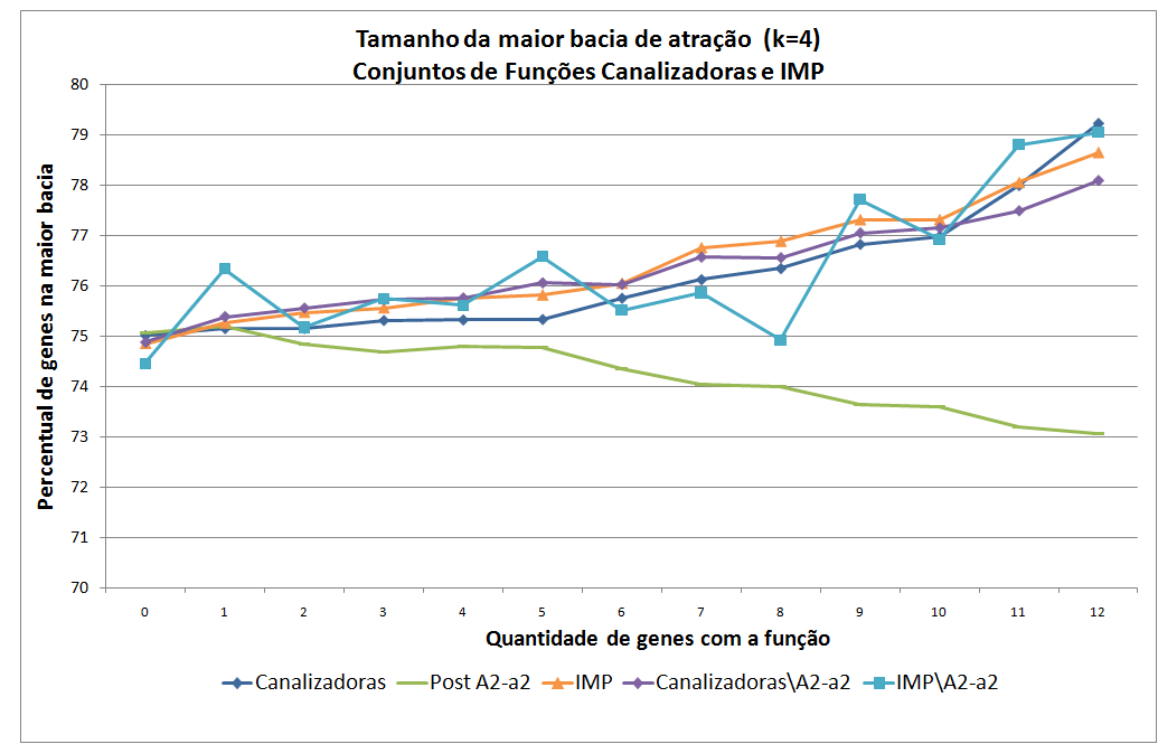

Figura 4.9: Tamanho da maior bacia de atração para redes construídas a partir de diferentes funções Booleanas em que $k=4$, gráfico dos conjuntos de funções Canalizadoras e IMP.

estabilidade. Logo, em uma primeira análise dos resultados obtidos, podemos perceber a controvérsia existente no estudo de estabilidade.

Como exemplo, podemos observar o desempenho das classes Post, $A^{2}-a^{2}$ e $A^{\infty}-a^{\infty}$. A classe $A^{2}-a^{2}$ possui uma tendência decrescente na Figura 4.9 (tamanho da maior bacia de atração), e a classe $A^{\infty}-a^{\infty}$ apresenta-se estável no mesmo gráfico. Ainda na mesma figura, as demais classes analisadas possuem uma tendência de aumento da quantidade de estados na maior bacia de atração.

Apesar do tamanho da maior bacia de atração apresentar tendência de queda nas funções de classe Post, essas funções se destacam na presença de atratores de tamanho 1, apresentando as maiores tendências de 
crescimento (Figura 4.5). As demais funções Booleanas não apresentam mudanças significativas em relação a $p=0$. Com esse resultado, podemos supor que o aumento de funções da classe Post torna mais estável a execução de um atrator, mas, na ocorrência de uma pertubação e se o sistema for conduzido a outro estado, a estabilidade é comprometida.

Analisando a interação entre as medidas realizadas é possível perceber, como esperado, que a redução da quantidade de atratores está relacionada ao aumento da quantidade de estados na maior bacia de atração. A quantidade de atratores da classe $A^{2}-a^{2}$ é a única que se apresenta estável em torno de $p=0$, rede em que todas as funções Booleanas são possíveis. É possível perceber que as redes com maior aumento da quantidade de estados na maior bacia de atração também apresentam redução na quantidade de atratores.

No comparativo entre o grupo de conjuntos relacionados a funções IMP (conjunto de funções IMP e conjunto "IMP sem $A^{2}-a^{2}$ ") e o grupo de conjuntos relacionados a funções canalizadoras (funções canalizadoras, funções canalizadoras aninhadas e "Canalizadoras em $A^{2}-a^{2}$ "), as diferenças qualitativas são claras. Ambos os grupos situam-se no mesmo patamar de crescimento da quantidade de estados na maior bacia de atração, mas o grupo de conjuntos IMP apresenta uma redução menor da quantidade de atratores. Esse resultado indica que o aumento de funções IMP em uma rede tende a "estabilizar" uma bacia de atração apenas reduzindo a quantidade de estados nas outras bacias, mas preservando os demais atratores.

Dentre todos os resultados encontrados, o comportamento das redes construídas a partir de funções de limiar são os mais interessantes. Essas redes apresentam um ponto ótimo da quantidade de funções de limiar em relação à estabilidade, em geral em torno de 9 ou 10 funções de limiar no total de 12 funções. A partir desse ponto ótimo, o tamanho da maior bacia de atração apresenta uma tendência de queda e a tendência de crescimento da quantidade de atratores de tamanho 1 é acentuada. Esse comportamento é difícil de ser interpretado e indica o potencial de estudo dessas funções em trabalhos futuros.

Os resultados das análises dos conjuntos "IMP sem $A^{2}-a^{2}$ " e "Canalizadoras sem $A^{2}-a^{2}$ " também são interessantes. O conjunto de funções "Canalizadoras sem $A^{2}-a^{2}$ " apresentou menos atratores e menos atratores de tamanho 1 que o conjunto de funções Canalizadoras, justamente as duas medidas em que a classe Post $A^{2}-a^{2}$ se destaca pelo crescimento.

O conjunto "IMP sem $A^{2}-a^{2}$ ", entretanto, não apresenta diferenças em relação ao conjunto de funções IMP. Evidentemente, a interação entre os conjuntos $A^{2}-a^{2}$ e $I M P$ (interseção em 278 funções Booleanas) é menor do que entre o primeiro e funções canalizadoras (interseção em 1896 funções Booleanas), o que dificulta a exibição de mudanças qualitativas nos gráficos.

Para trabalhos futuros, o estudo da interação entre grupos de funções Booleanas é um tema promissor. Nossa análise do conjunto de funções Booleanas poderia servir como um primeiro passo em um método de inferência de redes: como diferentes conjuntos implicam em redes com estabilidades distintas, esta informação poderia ser utilizada a priori em um método de inferência.

O uso de conjuntos de funções Booleanas também pode ser usado para limitar o espaço de busca de funções Booleanas na construção de uma rede. Como exemplo, apesar do espaço total de funções Booleanas de 4 variáveis possuir $2^{2^{4}}$ funções, o conjunto "Canalizadoras sem $A^{2}-a^{2}$ " possui apenas 1618 funções. Acreditamos que essa redução no espaço de busca seja de grande importância para estudos de evolução de redes de regulação ou Biologia Sintética.

Em conclusão, os resultados deste capítulo confirmam a hipótese amplamente trabalhada na literatura de que a escolha da função Booleana influi diretamente na estabilidade da rede e, a depender da medida de estabilidade buscada, um conjunto de funções Booleanas pode ser preferido ou preterido. 


\section{Capítulo 5}

\section{Canalização pelo tamanho da bacia de atração}

No capítulo anterior, o comportamento de diversas características de uma rede Booleana foi analisado. As medidas apresentadas possuem relação direta com a estabilidade de uma rede e, a priori, poderiam ser usadas como sinônimos de canalização.

Neste capítulo, nos concentramos na medida do tamanho da maior bacia de atração de uma rede Booleana. Essa medida, como apresentado na Seção 4.8.3, poder ser relacionada facilmente com o conceito de canalização. O objetivo deste capítulo é apresentar vantagens e/ou impactos da utilização dessa característica como um modelo para a canalização. Um estudo semelhante foi realizado por Boldhaus et. al [2], mas em relação à estabilidade da dinâmica como um todo, e não somente em relação à bacia de atração.

Nas seções seguintes, apresentamos estudos sobre a manutenção da maior bacia de atração de uma rede após modificações em suas conexões. Como será analisado no momento oportuno, é possível perceber a alta relação do modelo proposto com o comportamento de redes biológicas canalizadas.

Além desses experimentos, estudamos o impacto de nossa proposta na rede de regulação do ciclo celular da levedura. Essa rede, embora pequena, é amplamente conhecida na literatura e, portanto, possível de ser comparada com resultados teóricos. Nossas análises indicam que o modelo proposto é relacionado com os efeitos conhecidos da repressão de alguns genes no crescimento celular.

\subsection{Simplificações utilizadas}

Com o objetivo de simplificar as simulações e facilitar a interpretação dos resultados, algumas limitações ao modelo de redes Booleanas foram utilizadas nas análises deste capítulo.

Em nossas simulações, apenas redes Booleanas com funções de limiar simplificadas (3.1.3 e 4.6), aqui chamadas de TBN, são utilizadas. Conforme apresentado na Seção 3.1.3, essas redes são de fácil interpretação biológica.

Além das vantagens de interpretação, os resultados da Seção 4.6 apontam que redes construídas exclusivamente com esse conjunto de funções possuem atratores de tamanho 1 como maioria entre os atratores. Essa característica das TBN facilita a identificação das bacias de atração nas redes e permite que nossa análise seja focada nas bacias de atração de cada atrator.

Neste capítulo, a expressão "maior bacia de atração" foi substituída por "atrator majoritário". O termo "majoritário" foi escolhido por carregar o conceito de estabilidade proposto para essa medida.

\subsection{Estabilidade de uma TBN em relação a modificações estruturais}

Um fenótipo canalizado deve ser estável em relação a pequenas modificações nas interações gênicas. Se considerarmos o atrator majoritário como sendo um fenótipo canalizado, ele deve possuir essa estabilidade. Nesta seção, focamos na análise de redes submetidas a uma alteração em sua matriz $A$ de regulações gênicas. 
O seguinte método de modificação de uma rede é utilizado nesta seção. Seja $a_{i j}$ o elemento de $A$ selecionado para sofrer uma modificação. Se $a_{i j}=0$, então o novo valor de $a_{i j}$ será, com igual probabilidade, 1 ou -1 . Se $a_{i j} \neq 0$, então $a_{i j} \leftarrow 0$. Esse modelo permite o surgimento de novas conexões entre os genes e a perda de conexões prévias, eventos considerados biologicamente razoáveis.

\subsubsection{Resistência do atrator majoritário a uma única modificação}

O primeiro teste realizado verifica se o atrator majoritário continua sendo um atrator após sofrer uma modificação pontual. Uma mesma rede, com o atrator majoritário identificado, é submetida a uma modificação e considerada "resistente" se o atrator majoritário continuar como um atrator. Cada rede é submetida a 100 modificações aleatórias (não cumulativas), em um total de 100 redes. Em comparação, o mesmo teste é realizado em um atrator escolhido aleatoriamente. Os resultados para $n=12$ e $n=16$ estão plotados na Figura 5.1.

Os resultados indicam que atratores, majoritários ou não, são estáveis em relação a modificações pontuais. O grande desvio padrão da série de dados sobre os atratores majoritários, mas com uma média similar, em comparação aos atratores não-majoritários, mostra que uma TBN é capaz de gerar um atrator majoritário mais estável do que seus outros atratores. Os gráficos indicam ainda uma discreta tendência para atratores majoritários serem mais resistentes do que atratores escolhidos aleatoriamente em redes menos conexas.
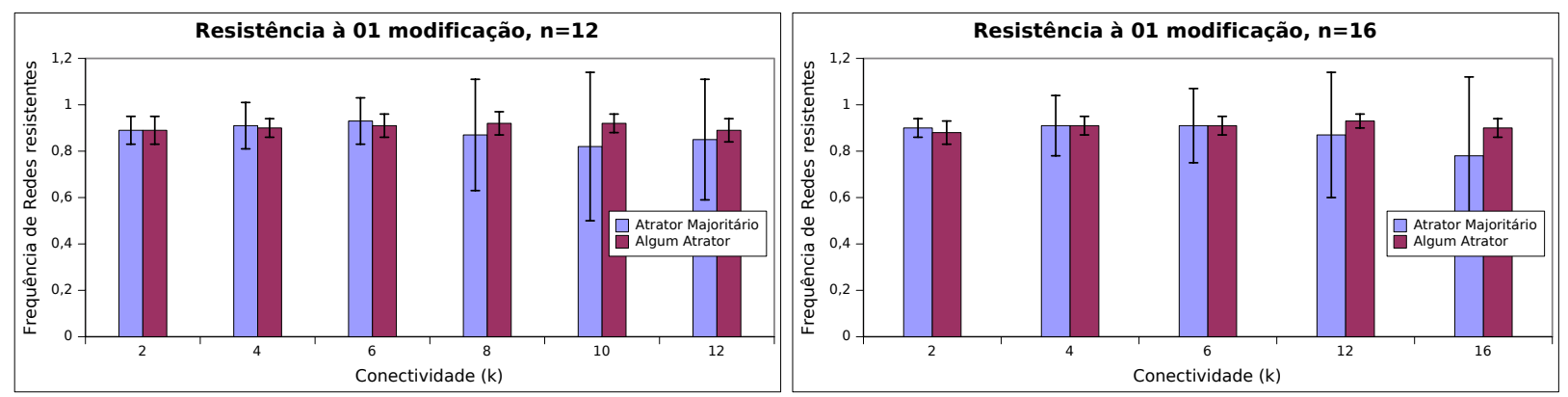

Figura 5.1: Capacidade de um atrator majoritário de resistir a uma modificação e permanecer como um atrator. Cada coluna do gráfico representa a média e o desvio padrão do histograma de 100 redes submetidas, cada uma, a 100 modificações. A mediana de todos os histogramas é acima de 0.9 .

Em condições semelhantes, analisamos a continuidade de um atrator majoritário como atrator majoritário em relação a uma modificação pontual. Os resultados para $n=12$ e $n=16$ estão presentes na Figura $5.2 \mathrm{e}$ indicam que em mais de $60 \%$ das redes, para diversos graus de conectividade, o atrator majoritário permanece como tal após uma modificação pontual.
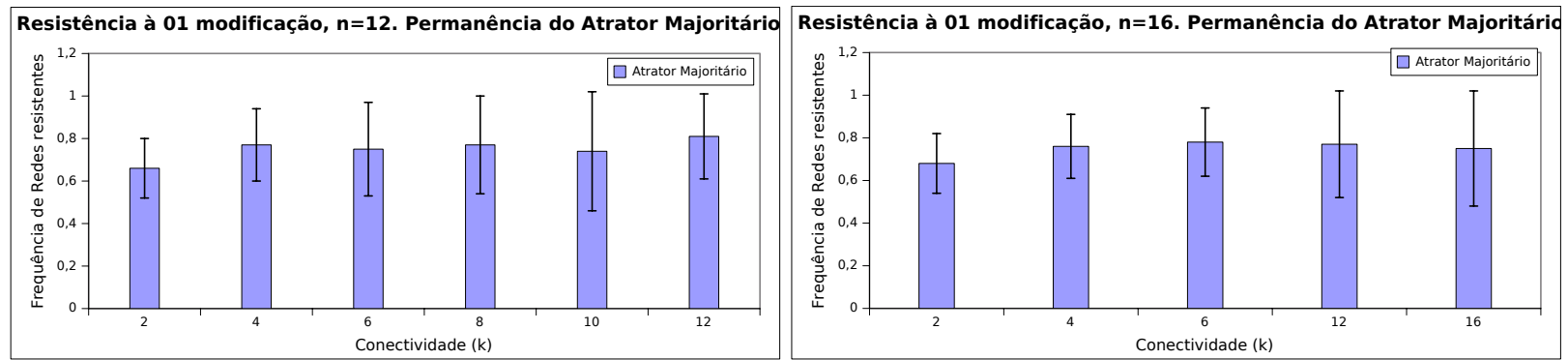

Figura 5.2: Capacidade de um atrator majoritário de resistir a uma modificação e permanecer como atrator majoritário. Cada coluna do gráfico representa a média e o desvio padrão do histograma de 100 redes submetidas, cada uma, a 100 modificações. A mediana de todos os histogramas é acima de 0.8 . 


\subsubsection{Resistência do atrator majoritário a $m$ modificações}

Os testes da seção anterior indicam que atratores majoritários são estáveis a uma modificação. Nesta seção, testaremos essa estabilidade em relação a $m$ modificações sucessivas. O modelo de modificação utilizado será o mesmo da seção anterior.

Primeiramente, a estabilidade de atratores majoritários para valores de $m$ entre 2 e 20 foi testada. As curvas para uma rede de $n=12$ e diversas conectividades estão plotadas na figura 5.3.

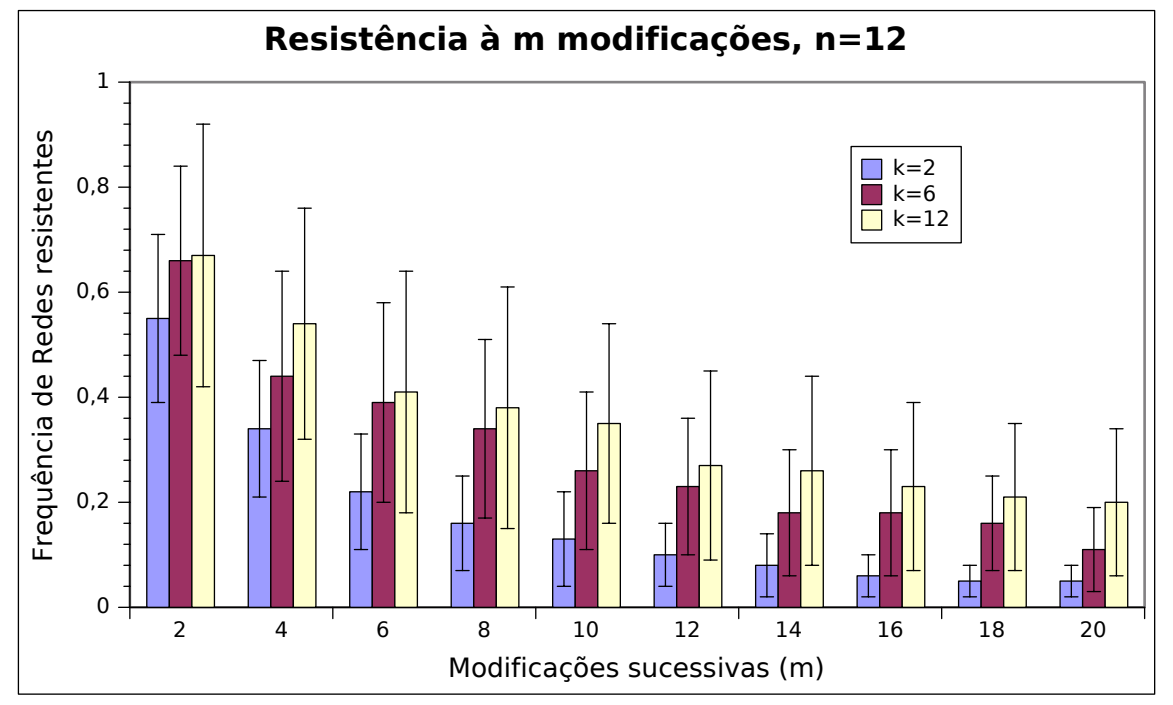

Figura 5.3: Capacidade de um atrator majoritário de resistir a $m$ modificações e permanecer como atrator majoritário. As três curvas do gráfico apresentam o comportamento para $k=2, k=6$ e $k=12$. Cada coluna do gráfico representa a média e o desvio padrão do histograma de 100 redes submetidas, cada uma, a $m=20$ modificações sucessivas. A mediana de todos os histogramas é similar à média.

Como podemos perceber, e como esperado, redes com maior grau de conectividade aparentam possuir maior resistência à modificação do atrator majoritário.

Esse resultado pode ser entendido intuitivamente. Em uma TBN com alta conectividade, podemos esperar que:

- Muitas conexões serão redundantes.

- O input em cada gene possuirá um módulo muito alto.

Com essas características, é razoável esperar que a modificação em uma TBN de alta conectividade possua um impacto menor do que em uma rede de baixa conectividade.

Se considerarmos o atrator majoritário como um fenótipo canalizado, uma conectividade suficiente para absorver o efeito das modificações parece ser uma característica importante que uma rede de regulação gênica deve possuir.

\subsection{Genes e interações que regulam a estabilidade de uma TBN}

As seções anteriores associaram um fenótipo canalizado a um atrator majoritário resistente a modificações. Entretanto, não há indicações de que todas as modificações possuam efeitos semelhantes na resistência de uma rede. 
Como dito na Seção 2.1.1, ao lado do conceito de canalização encontra-se o conceito de gene canalizador - o gene que, de alguma forma, garantiria a robustez. Nesta seção, estudamos a existência e o impacto desse conceito sob dois pontos de vista: conexões entre genes e genes inteiros como mantenedores da estabilidade.

Essa análise foi realizada na TBN proposta por Li et. al [33] para modelagem do ciclo celular da levedura. Essa rede, presente na Figura 5.4, contém 11 genes e 30 conexões. Estes genes representam os principais checkpoints do ciclo celular que envolve cerca de 800 genes [54]. Esta rede contém 3 grupos de genes: ciclinas (Cln3, Cln2, Clb2 e Clb5), complexos competidores das ciclinas (Sic1, Cdh1 e Cdc20) e fatores de transcrição (SBF, MBF, Mcm1 e Swi5).

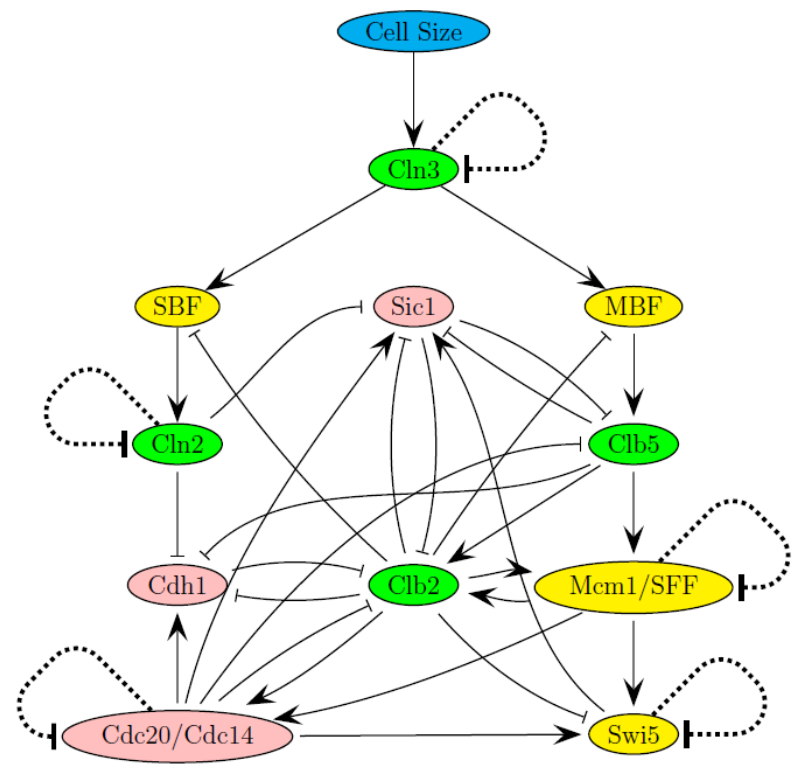

Figura 5.4: Rede de interação gênica para o ciclo celular da levedura. As arestas com setas representam interações promotoras e as arestas com barras representam inibições. Li et al. [33]. Em verde estão representadas as ciclinas, em rosa, seus competidores e em amarelo, os fatores de transcrição.

\subsubsection{Interações entre os genes como reguladoras da estabilidade}

Nesta seção, investigamos o efeito das conexões entre os genes na conservação do atrator majoritário.

Para tal, a cada conexão da matriz $A$ de uma rede será calculado um grau de canalização, $C\left(x_{i}, x_{j}\right)$, relacionado com o impacto do desligamento daquela conexão $\left(x_{i} \rightarrow x_{j}\right)$ na conservação do atrator majoritário. Por simplicidade, o grau de canalização só estará definido entre genes que possuam alguma interação.

Antes de detalhar o conceito de grau de canalização, podemos definir conexão canalizadora: uma conexão que, se retirada, compromete a estabilidade da rede.

Definição Seja $A$ a matriz de regulação de uma TBN $R$ e $M$ seu atrator com maior bacia de atração. Seja $A^{*}$ a matriz de regulação da rede $R^{*}$, com os mesmos elementos de $A$, exceto por $a_{i j}=0$, para algum $i, j$, e $M^{*}$ o atrator de $R^{*}$ com a maior bacia de atração. Definimos por conexão canalizadora o par $\left(x_{i}, x_{j}\right)$ se $M \neq M^{*}$.

Caso a conexão mantenha o atrator majoritário na rede modificada, o grau de canalização da conexão entre os genes $x_{i}$ e $x_{j}$ será definido de acordo com o tamanho do atrator majoritário na rede originial e com o tamanho do atrator majoritário na rede modificada. 
Definição Seja $A$ a matriz de regulação de uma TBN $R$ e $M$ seu atrator com maior bacia de atração. Seja $A^{*}$ a matriz de regulação da rede $R^{*}$, com os mesmos elementos de $A$, exceto por $a_{i j}=0$, para algum $i, j$, e $M^{*}$ o atrator de $R^{*}$ com a maior bacia de atração. Seja $\operatorname{basin}(M)$ a função que retorna o tamanho da bacia de atração a $M$. Se $M=M^{*}$, o grau de canalização, $C\left(x_{i}, x_{j}\right)$, entre duas conexões $\left(x_{i}, x_{j}\right)$ é definido por:

$$
C\left(x_{i}, x_{j}\right)=\left|\frac{\operatorname{basin}\left(M^{*}\right)}{\operatorname{basin}(M)}-1\right|
$$

As duas definições acima foram aplicadas na TBN do ciclo celular da levedura. Todas as conexões, separadamente, foram retiradas e identificadas como canalizadoras, ou, caso contrário, seu grau de canalização foi computado.

A Tabela 5.1 apresenta as oito conexões que, se alteradas, modificam o atrator majoritário - as conexões canalizadoras encontradas na rede da levedura. Logo, podemos considerar essas conexões necessárias para a existência do fenótipo canalizado e podemos esperar que as mesmas não se modifiquem em uma população. O conjunto de oito conexões contém 7 ciclinas, 6 competidores e 3 fatores de transcrição. Esta distribuição apresenta uma aversão significativa pelos fatores de transcrição, o que pode indicar uma importância relativamente menor destes genes no controle do ciclo celular.

\begin{tabular}{|c|c|c|}
\hline \multicolumn{3}{|c|}{ Conexões canalizadoras } \\
\hline Alvo & Preditor & Conexão \\
\hline MBF & Clb1 & -1 \\
\hline SBF & Clb1 & -1 \\
\hline Cln1 & SBF & 1 \\
\hline Swi5 & Mcm1 & 1 \\
\hline Clb5 & Cdc20 & -1 \\
\hline Sic1 & Cln1 & -1 \\
\hline Sic1 & Clb1 & -1 \\
\hline Clb1 & Mcm1 & 1 \\
\hline
\end{tabular}

Tabela 5.1: Tabela de conexões canalizadoras para a rede do ciclo celular da levedura.

A Figura 5.5 contém o gráfico do grau de canalização de 22 conexões. É possível perceber que algumas conexões, mesmo mantendo o atrator majoritário, modificam radicalmente a bacia de atração, relacionada com o ciclo celular e com a robustez do fenótipo. Podemos esperar que, na população, a existência dessas conexões seja inversamente proporcional ao seu grau de canalização.

Entretanto, esse cálculo, apesar de ser capaz de ordenar as interações com base em sua essencialidade, é de difícil comprovação biológica. Logo, uma abordagem mais generalista faz-se necessária.

\subsubsection{Genes como reguladores da estabilidade}

Nesta seção analisamos o efeito do desligamento das conexões de cada um dos genes e seu efeito na manutenção do atrator majoritário. Dados sobre o efeito do desligamento integral de genes no fenótipo são mais fáceis de serem obtidos experimentalmente.

Realizamos essa análise na rede proposta por Li et al. [33] para modelagem do ciclo celular da levedura (Figura 5.4). Os resultados são comparados com dados experimentais.

\section{Medidas sobre a modificação do atrator majoritário}

O método para identificarmos o efeito do desligamento de cada gene no atrator majoritário será semelhante ao da seção anterior. Para cada gene $x_{i}$, sua influência em outros genes será deletada da rede $\left(a_{j i} \leftarrow 0\right)$ 


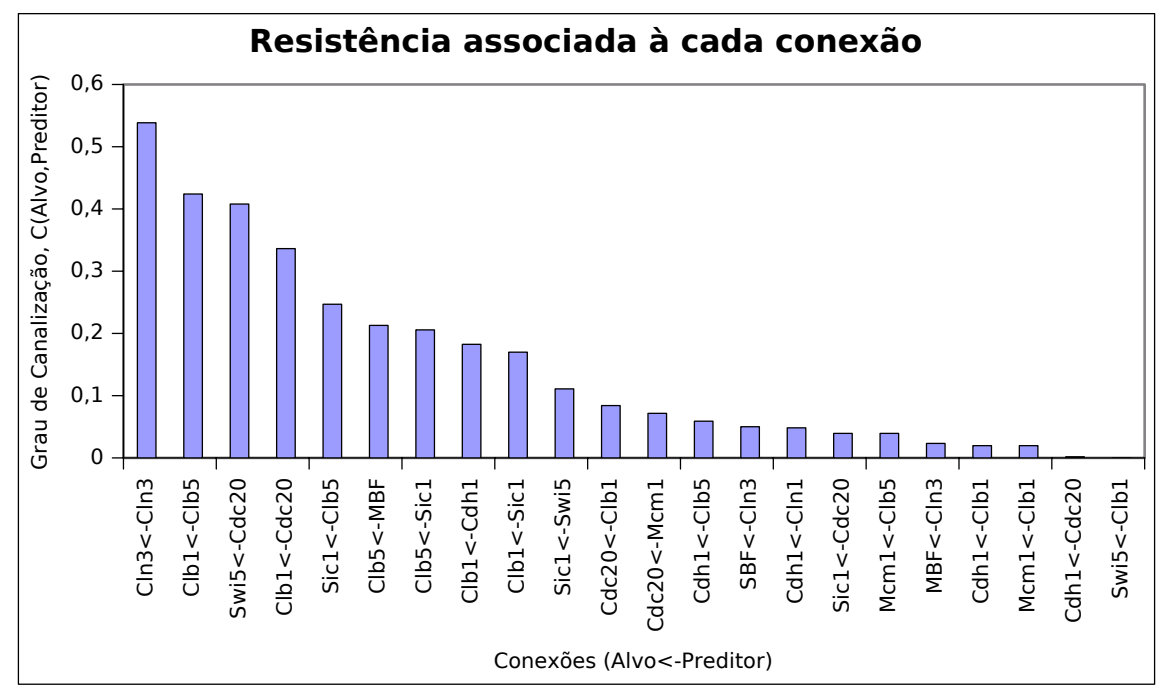

Figura 5.5: Resistência de cada conexão à modificação, calculada a partir do grau de canalização, $C\left(x_{i}, x_{j}\right)$. O desligamento de algumas conexões modifica de forma significativa a bacia de atração do atrator majoritário.

e os efeitos no atrator majoritário serão investigados.

Para essa análise, definimos função identificadora de modificação do atrator majoritário $I\left(x_{i}\right)$ por um gene $x_{i}$.

Definição Seja $A$ a matriz de regulação de uma TBN $R$ e $M$ seu atrator com maior bacia de atração. Seja $A^{*}$ a matriz de regulação da rede $R^{*}$, com os mesmos elementos de $A$, exceto por $a_{i j}=0$, para algum $i$ e para todo os valores de $j$, e $M^{*}$ o atrator de $R^{*}$ com a maior bacia de atração. A função identificadora de modificação $I\left(x_{i}\right)$ está definida como:

$$
I\left(x_{i}\right)= \begin{cases}0, & \text { se } M^{*}=M \\ 1, & \text { se } M^{*} \neq M\end{cases}
$$

No entanto, há casos em que o atrator majoritário se mantém, mas sua bacia de atração tem seu formato radicalmente alterado. E há também casos em que o estado correspondente ao atrator majoritário se modifica, mas sua bacia de atração pode permanecer semelhante. Para considerarmos esses efeitos em nossa análise, estendemos o conceito de grau de canalização de uma conexão da seção anterior para um gene inteiro.

Definição Seja $A$ a matriz de regulação de uma TBN $R$ e $M$ seu atrator com maior bacia de atração. Seja $A^{*}$ a matriz de regulação da rede $R^{*}$, com os mesmos elementos de $A$, exceto por $a_{i j}=0$, para algum $i$ e para todo os valores de $j$, e $M^{*}$ o atrator de $R^{*}$ com a maior bacia de atração. Seja $\operatorname{basin}(M)$ a função que retorna o tamanho da bacia de atração a $M$. O grau de canalização, $C\left(x_{i}\right)$, de um gene $x_{i}$ é definido por:

$$
C\left(x_{i}\right)=\left|\frac{b a \sin \left(M^{*}\right)}{\operatorname{basin}(M)}-1\right|
$$

Tipicamente, $C\left(x_{i}\right)<1$.

Ambas as funções $I\left(x_{i}\right)$ e $C\left(x_{i}\right)$ são construídas para que tenham valor 0 em casos de modificações pequenas no atrator majoritário e 1 em casos de grandes mudanças. Os resultados da aplicação de ambas as funções na rede do ciclo celular da levedura serão comparados com dados experimentais. 


\section{Dados Biológicos}

O banco de dados presente no Saccharomyces Genome Database ${ }^{1}$ contém uma grande variedade de informações sobre a Saccharomyces Cerevisae, inclusive dados sobre a atuação de cada um de seus genes, provenientes de centenas de trabalhos curados.

Para nossa comparação, pesquisamos no banco de dados os efeitos da deleção de cada um dos genes presentes no ciclo celular da levedura. Apesar de serem genes envolvidos no ciclo celular, a deleção de cada gene provoca uma grande quantidade de variações fenotípicas, como modificação na resistência a drogas e ao calor, além de variações no crescimento, formato e tempo de reprodução.

Muitas das medidas relacionadas com mutações de um gene são ainda provenientes de trabalhos diversos, o que complica a análise se estivermos interessados em dados quantitativos, já que os experimentos podem ter sido realizados em condições diferentes.

Dentre todos os artigos listados no SGD, o trabalho de Breslow et. al [4], de 2008, chama a atenção. Esse trabalho apresenta uma nova técnica para a medição, em alta resolução, da análise funcional do genoma. A quase totalidade dos genes da levedura é retirada ${ }^{2}$ e o crescimento da colônia de mutantes é comparado com o crescimento de uma colônia wild type. Aplicando essa análise para quase todo o genoma, o artigo conclui que a grande maioria dos genes, quando deletada, acarreta desvantagem no crescimento do organismo.

Para nossa comparação, o trabalho de Breslow et al. [4] apresenta duas vantagens:

- Calcula, para cada gene, um índice de competitive fitness, composto pela razão entre o crescimento da colônia mutante e o da colônia wild type.

- Realiza experimentos em condições similares para quase todos os genes envolvidos no ciclo celular da levedura.

\section{Resultados}

Os dados de Breslow et. al [4] apresentam um experimento para dez dos 11 genes do ciclo celular da levedura. Desses dez, sete foram submetidos à deleção e três à redução de atividade.

Como dispomos de poucos genes para serem analisados, a comparação com as funções $C\left(x_{i}\right)$ e $I\left(x_{i}\right)$ foi feita de forma qualitativa. A Tabela 5.2 exibe os valores das funções e o competitive fitness de cada gene.

A Tabela 5.3 traz a consolidação por grupo de genes dos indicadores $C\left(x_{i}\right)$ e dos dados de Deleção \&Redução, através de uma média simples. O grupo de fatores de transcrição apresenta baixos valores para ambos os indicadores, o que pode implicar na baixa significância deste grupo para a regulação do ciclo celular da levedura.

Para que fosse possível ser feita uma análise separada para cada função, dois gráficos foram construídos a partir de seu desempenho com os dados de deleção e redução considerados conjuntamente.

A Figura 5.6 separa em cores distintas genes que apresentaram ou não mudança do atrator majoritário. Como é possível perceber, os genes cujo desligamento não influencia na manutenção do atrator majoritário mostram uma tendência de competitive fitness maior e mais estável do que os genes cujo desligamento muda o atrator.

Na Figura 5.7, comparamos a função $C(x)$, no eixo horizontal, com o competitive fitness de cada gene. Novamente, dividimos os grupos de genes de acordo com o desempenho de $I(x)$. Ambos os conjuntos de pontos (cores distintas) apresentam uma tendência de queda do competitive fitness em relação ao grau de canalização.

\footnotetext{
${ }^{1}$ http://www.yeastgenome.org/

${ }^{2}$ retirados um a um
} 


\begin{tabular}{|c|c|c|c|c|c|}
\hline \multicolumn{7}{|c|}{ Comparação entre índices teóricos e práticos } \\
\hline Nome YDB & Nome Gene & $I\left(x_{i}\right)$ & $C\left(x_{i}\right)$ & Deleção [4] & Deleção \& Redução [4] \\
\hline YAL040C & cln3 & 0 & 0.515 & 0.962 & 0.962 \\
\hline YKL112W & sbf & 0 & 0.226 & & 0.985 \\
\hline YLR079W & sic1 & 1 & 0.068 & 0.711 & 0.711 \\
\hline YOR298C-A & mbf & 0 & 0.303 & 0.983 & 0.983 \\
\hline YPL256C & cln2 & 1 & 0.446 & 0.711 & 0.711 \\
\hline YPR120C & clb5 & 0 & 0.484 & 0.974 & 0.974 \\
\hline YGL003C & cdh1 & 0 & 0.031 & & \\
\hline YPR119W & clb2 & 1 & 0.274 & 0.961 & 0.961 \\
\hline YMR043W & mcm1 & 1 & 0.187 & & 1.008 \\
\hline YGL116W & cdc20 & 1 & 0.226 & & 0.998 \\
\hline YDR146C & swi5 & 1 & 0.226 & 0.838 & 0.838 \\
\hline
\end{tabular}

Tabela 5.2: Comparação entre os índices $I(x)$ e $C(x)$ de cada gene com seu competitive fitness, calculado por Breslow et. al. [4].

\begin{tabular}{|c|c|c|}
\hline \multicolumn{3}{|c|}{ Média dos indicadores teóricos e práticos } \\
\hline Grupo & Média de $C\left(x_{i}\right)$ & Média de Deleção \& Redução \\
\hline Ciclinas & 0.4298 & 0.902 \\
\hline Competidores & 0.2355 & 0.9535 \\
\hline Fatores de transcrição & 0.1083 & 0.8545 \\
\hline
\end{tabular}

Tabela 5.3: Comparação entre os índices $I(x)$ e $C(x)$ de cada gene com seu competitive fitness, calculado por Breslow et. al. [4].

\subsection{Conclusão}

As análises deste capítulo foram consequência da associação fenótipo canalizado $\Leftrightarrow$ atrator majoritário. Os resultados obtidos abrem espaço para algumas considerações.

O primeiro ponto a ser discutido é a resistência dos atratores majoritários a modificações. A Seção 5.2.1 mostra que a modelagem por TBN confere aos atratores grande resistência a pequenas modificações, particularmente aos atratores majoritários. Esse resultado confere validade ao modelo, uma vez que se espera um certo grau de resiliência de um fenótipo em uma população. A seção também indica a tendência de atratores majoritários serem mais resistentes a modificações do que um atrator típico. Em trabalhos futuros, cabe o esclarecimento dessa tendência e de outras vantagens dos atratores majoritários.

$\mathrm{O}$ resultado da Seção 5.2.2, que associa a alta conectividade da rede à resistência dos atratores majoritários, também possui uma implicação biológica interessante. Se, por um lado, o aumento da conectividade representa um aumento da quantidade de reações químicas envolvidas na regulação gênica, por outro, esses resultados indicam que esse aumento de conectividade pode ser necessário para a canalização de uma característica.

O método contido na Seção 5.3 propõe uma forma simples de se identificar relações de regulação gênica necessárias para a manutenção de um fenótipo canalizado. Evidentemente, uma validação biológica exaustiva deve ser executada antes que possamos considerar esse um método de identificação de conexões canalizadoras, embora possamos percebê-lo como um primeiro passo teórico.

Na Seção 5.3.2, ao desligarmos todas as conexões de um gene, os resultados mostram um comportamento qualitativo significativo. Genes cujo desligamento altera o atrator majoritário aparentaram ser essenciais para o crescimento da levedura em experimentos. Além disso, quanto maior a modificação do atrator majoritário, maior é a essencialidade de um gene no mesmo experimento. 


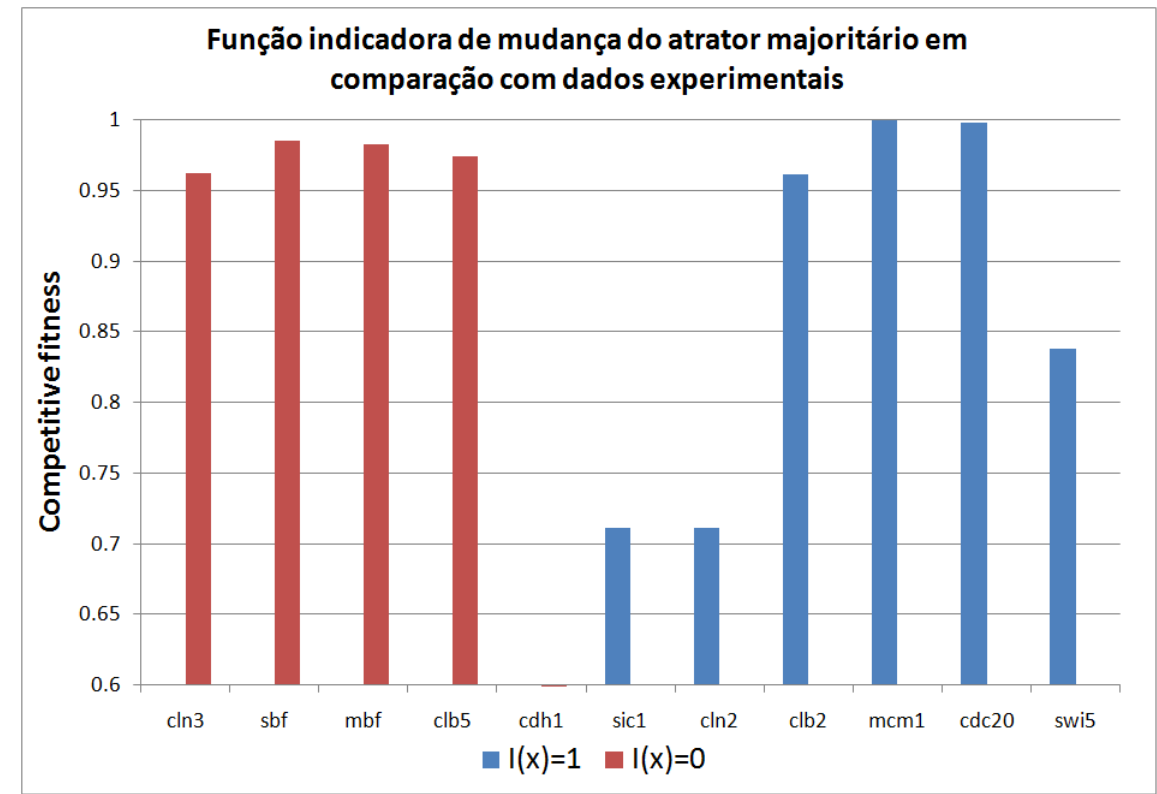

Figura 5.6: Comparação entre os dois valores possíveis da função $I(x)$ com dados experimentais.

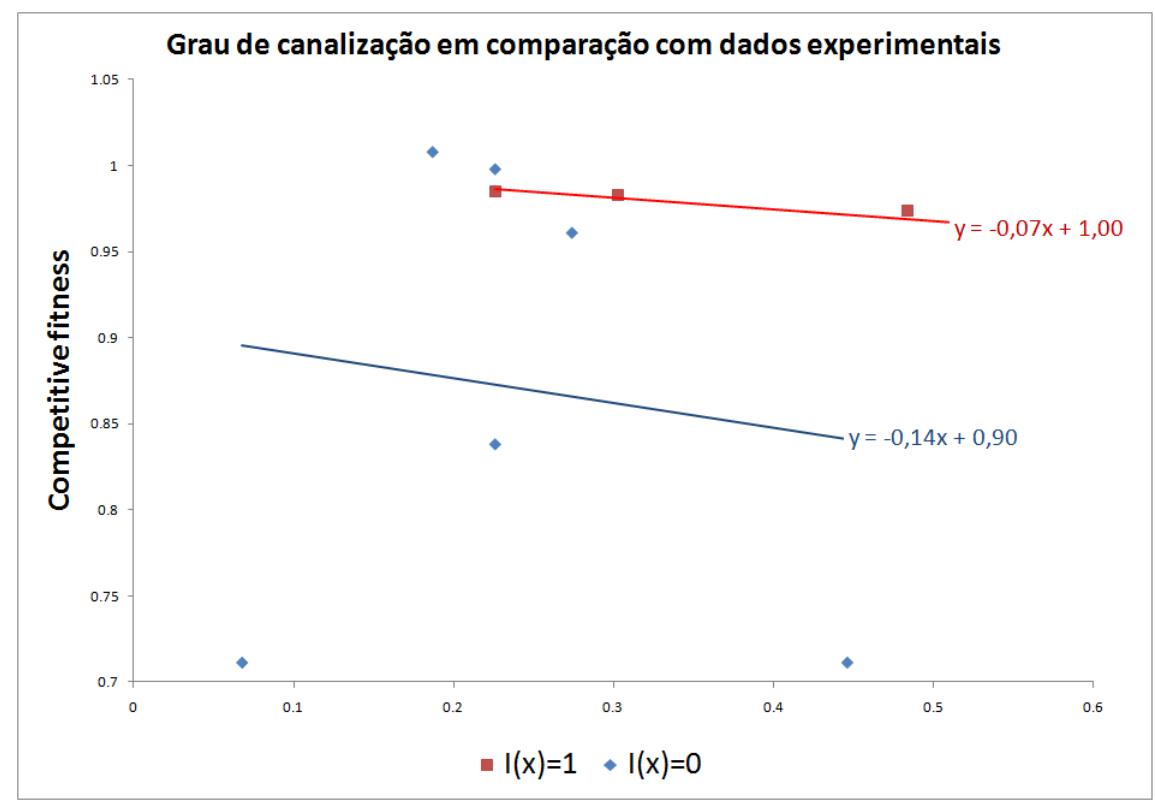

Figura 5.7: Comparação entre os possíveis valores da função $C(x)$ (eixo horizontal) com dados experimentais (eixo vertical). Os conjuntos de dados equivalentes a $I(x)=0$ e $I(x)=1$ foram marcados com cores distintas.

As Seções 5.3 e 5.3.2 trazem ainda conclusões semelhantes em relação ao grupo de genes fatores de transcrição na rede do ciclo celular da levedura. Em ambos os casos, a importância deste grupo de genes para a manutenção do atrator majoritário, e consequente estabilidade da rede, foi baixa. Apesar do tamanho reduzido da rede analisada, estes resultados nos levam a acreditam que o conjunto de genes fator de transcrição está sub-representado, e que talvez mais conexões ou genes devessem ser acrescentadas ao modelo.

Embora as conclusões possam não ser tão impactantes, já que a falta de dados impede a validação dessas medidas com critérios quantitativos, nossa análise indica que a manutenção do atrator majoritário e o grau 
de canalização de um gene são índices relevantes no estudo do tamanho da maior bacia de atração como critério de estabilidade.

Com o aprimoramento dos métodos descritos neste capítulo, podemos apresentar, para a continuidade de um fenótipo, um procedimento de identificação de interações gênicas, de genes que não podem ser alterados ou de conexões que não podem ser inseridas.

Em conclusão, a consideração de que o tamanho da maior bacia de atração - o atrator majoritário representa a estabilidade - ou a canalização - mostra-se adequada. A partir dessa medida, considerações teóricas sobre a topologia das redes de regulação, assim como análises preliminares sobre a estabilidade de uma rede conhecida, podem ser realizadas. 


\section{Capítulo 6}

\section{Funções Booleanas e topologias da rede de regulação}

Como visto no Capítulo 4, as funções Booleanas desempenham um claro papel na estabilidade de uma rede. Intuitivamente, podemos imaginar uma função Booleana como uma promotora de estabilidade local. Se uma rede é construída de tal forma que todas as suas funções Booleanas pertençam a um mesmo conjunto que possui características promotoras de estabilidade, como funções canalizadoras, podemos concluir que a estabilidade da rede foi construída através da estabilidade local de todos os seus nós.

Além de aspectos relacionados à estabilidade, o estudo de rede Booleanas revela importantes orientações sobre a construção e o funcionamento dessas redes enquanto redes biológicas. Entretanto, a partir de um certo patamar da quantidade de nós, considerações sobre a topologia da rede, isto é, sobre a forma como seus nós estão conectados/agrupados, tornam-se necessárias.

Dessa forma, paralelamente ao estudo de redes Booleanas, e principalmente devido aos trabalhos de Barabási, estudos das propriedades das topologias de redes têm sido realizados na literatura sob a denominação de "Redes Complexas". Historicamente, análises típicas de redes complexas são realizadas em redes grandes, como a Internet, ou em redes de interação social, já que topologias de rede são distinguíveis apenas nesses casos.

Dentre as análises mais comuns, muitos trabalhos de redes complexas estudam a estabilidade de redes. Em muitos casos, topologias são formuladas para conferir maior ou menor resistência da rede a modificações. Como uma topologia é uma característica intrínseca a uma rede, podemos chamar de "estabilidade global" a estabilidade resultante de uma determinada topologia.

Se pensarmos na união desses dois conceitos, poucos trabalhos se preocuparam com a escolha de diferentes funções Booleanas em diferentes topologias ou, de uma forma genérica, com o impacto dos promotores de estabilidade local na estabilidade global.

Para o conceito biológico de canalização de características, essa análise é fundamental. Como visto, os fatores responsáveis pela canalização de uma determinada característica não são totalmente compreendidos, embora muitos estudos indiquem o papel de certos genes, muitas vezes responsáveis pela regulação de uma variedade de outros processos, como uma característica essencial. Se a canalização é resultado de uma certa topologia, de um certo conjunto de funções Booleanas ou do resultado de uma interação entre ambos é ainda uma informação desconhecida.

Neste capítulo, essa interação é investigada de acordo com o tamanho da maior bacia de atração de uma rede Booleana. Tendo em vista a interpretação dos resultados obtidos sob o ponto de vista biológico, já que relacionamos o tamanho da maior bacia de atração com o conceito de canalização de características, verificamos a estabilidade de dois conjuntos de funções Booleanas em diferentes topologias de rede.

Na próxima seção, apresentamos o conceito de Redes Complexas e as topologias utilizadas neste estudo. 
Em seguida, descrevemos a metodologia e os resultados obtidos. As duas últimas seções contêm uma análise dos dados e a sua interpretação em relação à canalização de características.

\subsection{Redes Complexas}

No escopo deste trabalho, uma rede é definida como um grafo direcional. Nesse contexto, chamamos de grau de entrada a quantidade de arestas que se dirigem a um nó e de grau de saída a quantidade de arestas que partem de um nó. Na Seção 3.1, é possível encontrar uma revisão dos conceitos de redes Booleanas aqui utilizados.

Uma rede é caracterizada como "Rede Complexa" se sua topologia apresentar características não-triviais. Evidentemente, a definição de trivialidade pode variar e, dessa forma, podemos dizer que uma rede torna-se "complexa" se um determinado estudo estiver relacionado com a topologia da mesma.

Nesta seção, apresentamos as topologias das redes utilizadas neste trabalho. Como é possível perceber, algumas topologias tornam-se evidentes apenas quando a quantidade de nós for relevante. Após essa breve introdução, alguns trabalhos sobre a interação entre redes Booleanas e redes Complexas serão revistos.

\subsubsection{Redes livres de escala}

As redes livres de escala, ou redes scale-free, talvez sejam as redes mais estudadas no âmbito das redes complexas. Uma rede é caracterizada como livre de escala se a distribuição dos graus de saída $x$ de seus nós seguir uma função $x^{-\lambda}, \lambda>0$.

Uma rede com tal propriedade apresenta uma grande quantidade de nós com grau de saída pequeno, ou seja, de nós responsáveis pela regulação de poucos outros genes. Entretanto, tal rede também apresenta uma quantidade não-desprezível de hubs - nós com grau de saída elevado - já que a função $x^{-\lambda}$ não converge rapidamente para zero.

Essa topologia pode ser encontrada em diversas situações na natureza: na rede de conexões dos compostos utilizados pelo metabolismo humano, em redes de interações entre participantes de um ecossistema etc. Redes criadas por atividades humanas também demonstraram ser livres de escala, como a rede de conexões de websites na Internet, as redes de interações sociais entre os indivíduos, as redes de acionistas de um mesmo mercado e muitas outras. Um exemplo pode ser encontrado na Figura 6.1.

Em resumo, redes livres de escala apresentam uma quantidade considerável de hubs que regulam diversos nós com grau de saída pequeno. Por simplicidade, este trabalho considera o grau de entrada das redes constante com valor $k=4$.

Redes livres de escalas podem ser construídas através do princípio do atrelamento preferencial ${ }^{1}$ : um novo nó a ser incluído na rede tem probabilidade de ser regulado por um nó $n$ proporcional ao grau de saída de $n$. Dessa forma, nós com altos graus de saída tendem a aumentá-los, consolidando sua posição de hubs.

\subsubsection{Redes com um Hub central}

Uma simplificação trivial das redes livres de escala é uma rede em que a totalidade dos nós possui grau de saída pequeno, com exceção de um nó central, chamado de hub, que participa da regulação de todos os demais.

Apesar de apresentar uma topologia simplificada, essa rede pode ser relacionada com vários processos biológicos. Algumas proteínas, como a HSP90 e outras chaperones, são conhecidas pela atuação em diversos processos celulares. Um exemplo pode ser encontrado na Figura 6.2.

\footnotetext{
${ }^{1}$ ou efeito de Mateus: "Porque a todo o que tem se lhe dará, e terá em abundância; mas ao que não tem, até o que tem lhe será tirado." (Mateus 25:29)
} 


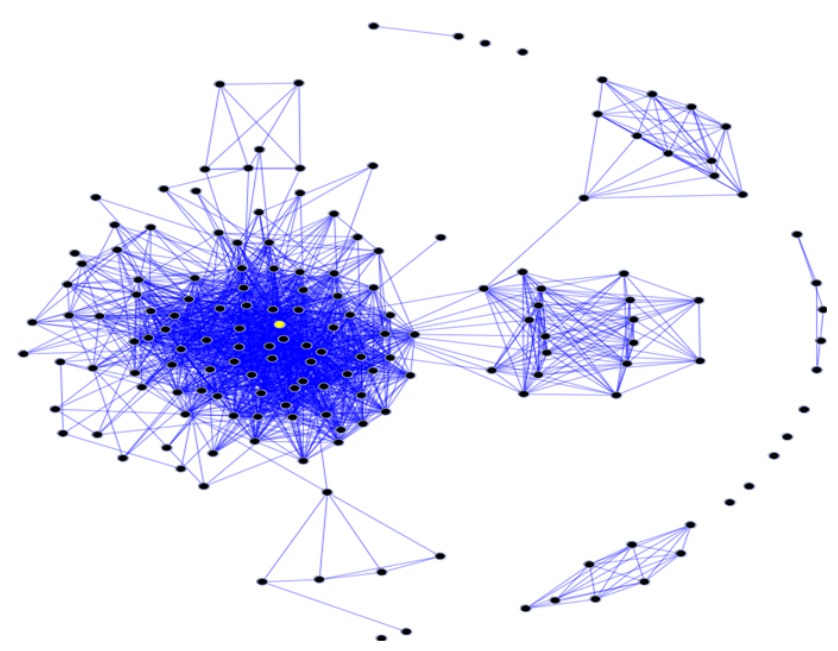

Figura 6.1: Exemplo de rede livre de escala, em que a quantidade de hubs não é desprezível. Figura retirada de http://en.wikipedia.org.

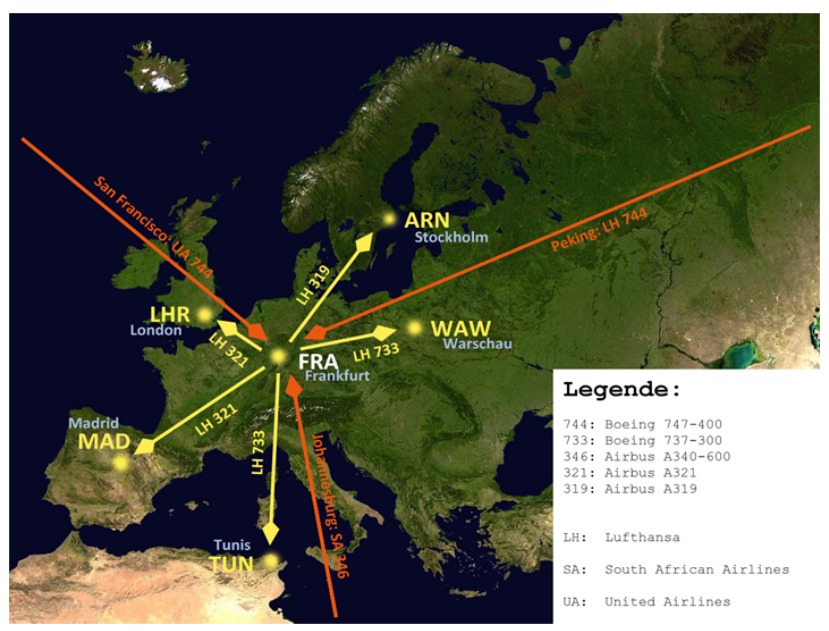

Figura 6.2: Exemplo de rede com um Hub central: conexões entre aeroportos na Europa. Figura retirada de http://en.wikipedia.org.

Podemos interpretar uma rede construída com essa topologia como o subgrafo de uma rede livre de escala que considera apenas um hub e seus regulados.

\subsubsection{Redes em árvore}

Uma rede é considera em árvore se existe um nó, chamado de nó raiz, a partir do qual existe uma árvore binária - um subgrafo - que compreende todos os demais nós da rede. Uma representação desta rede pode ser encontrada na Figura 6.3.

A existência de uma árvore a partir de um nó garante a uma rede dessa topologia que todos os seus nós são acessíveis, sem a criação de hubs típicos das redes livres de escala.

Como a árvore existente em redes dessa topologia é um subgrafo incompleto, redes com essa topologia são muito semelhantes a redes aleatórias em relação à distribuição dos graus de saída. 


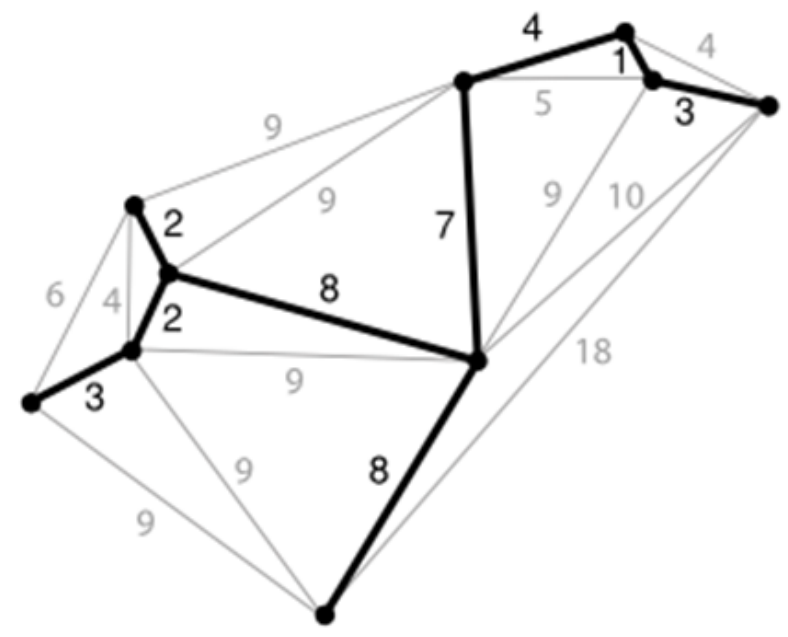

Figura 6.3: Exemplo de rede em árvore, em que existe uma árvore de funções Booleanas inscrita no grafo da rede. Figura retirada de http://en.wikipedia.org.

\subsubsection{Redes Complexas e redes Booleanas na literatura}

A utilização de conceitos do estudo de redes Complexas em redes Booleanas já foi alvo de alguns estudos na literatura recente.

Em um artigo de 2007, Iguchi et.al [18] investiga a influência da topologia livre de escala na quantidade de estados no ciclo de um atrator de uma rede Booleana. No mesmo grupo de trabalhos, Kinoshita et. al [17] estuda a estabilidade de redes Booleanas livres de escala em relação à mudança do estado de um nó. Nesse estudo, os autores identificam os hubs da rede como elementos que potencialmente podem propagar a instabilidade, já que se encontram conectados a muitos outros estados.

Dois artigos mais recentes tratam de topologias genéricas e suas implicações em redes Booleanas. Pomerance et. al [40], de 2009, investiga a estabilidade de redes - novamente em relação ao flip do valor de um nó construídas sob topologias genéricas e Zou [67], de 2010, propõe um método de construção de redes a partir de informações sobre a topologia e sobre o estado de equilíbrio da célula.

Ramo et. al [45] realiza uma análise semelhante à proposta deste trabalho ao estudar como a escolha da classe de funções Booleanas modifica a estabilidade da rede para diferentes distribuições de graus de entrada e saída na rede. Grefenstette et. al [12] propõe um modelo de redes Booleanas no qual considerações sobre as reações químicas, a topologia e a classe de funções Booleanas são utilizadas.

\subsection{Metodologia}

Potencialmente, a interação entre topologia e funções Booleanas de uma rede poderia ser analisada de diversas formas. Neste capítulo, foi escolhida uma abordagem simplificada mas ainda capaz de exibir um comportamento qualitativo interessante em relação à estabilidade.

Para limitar o escopo do estudo, as funções Booleanas escolhidas foram as que apresentaram melhores resultados em relação à estabilidade - medida em redes pequenas na Seção 4.8.3 - e que ainda possuíam uma cardinalidade significativa: funções Canalizadoras e funções IMP determinísticas.

Os resultados encontrados foram gerados a partir de redes construídas com as 3 topologias listadas na seção anterior, juntamente com diferentes percentuais de funções canalizadoras e funções IMP determinísticas. Essas redes foram submetidas à análise da estabilidade relacionada com o tamanho da maior 


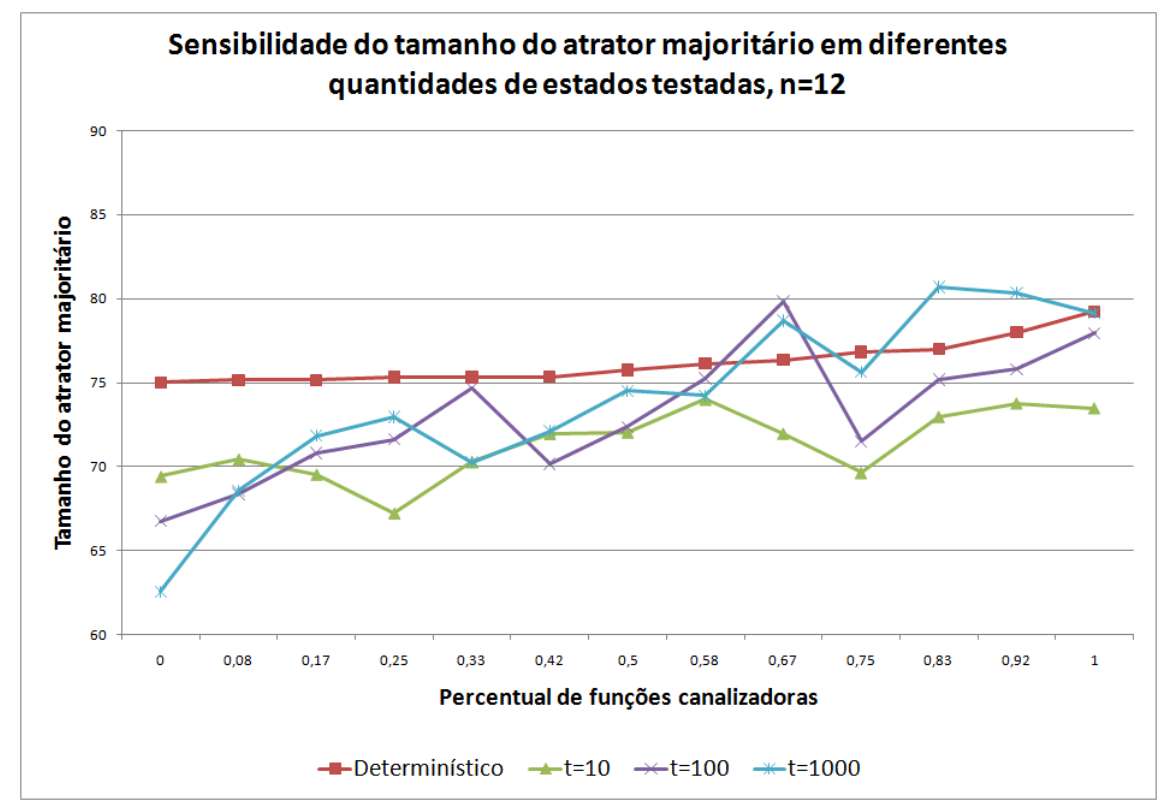

Figura 6.4: Sensibilidade da medida do tamanho do atrator majoritário para diferentes quantidades $t$ de estados na amostragem.

bacia de atração, semelhantemente à Seção 4.8.3.

Redes com cinquenta nós, $n=50$ e grau de entrada quatro, $k=4$, foram analisadas. Como a quantidade de nós existente inviabiliza a determinação da bacia de atração de todos os $2^{50}$ estados, uma abordagem "monte carlo" foi escolhida para a análise da estabilidade. Mil estados foram selecionados aleatoriamente e suas bacias de atração foram identificadas. A bacia de atração que foi contabilizada mais vezes a partir desses 1000 estados foi considerada a maior bacia de atração e o percentual de vezes em que esta bacia foi encontrada foi considerado seu tamanho.

A quantidade total de estados em uma rede de $n=50$ garante que a probabilidade de um estado ser escolhido repetidamente na amostragem acima seja desprezível. Contudo, a representatividade desse processo poderia ser questionada, já que $10^{3} \ll 2^{50}$.

Para investigar a validade de nossa amostragem, a quantidade de estados da amostragem foi comparada com a estabilidade de uma rede pequena, $n=12$, em que a mesma medida determinística poderia ser realizada. Os resultados presentes na Figura 6.4 indicam que, qualitativamente, as simulações realizadas em que $t$ representa a quantidade de estados da amostragem - convergem para o valor determinístico. Como não nos dispusemos a realizar análises finas sobre nossos dados, apenas comparações, essa abordagem foi considerada adequada.

\subsection{Resultados}

Inicialmente, a metodologia apresentada foi testada em uma rede pequena, com $n=12$, e somente para funções Canalizadoras. Juntamente com a estabilidade das três topologias citadas, acrescentamos ao gráfico medidas provenientes de amostragem aleatória e uma análise de todos os estados da rede em uma rede com topologia aleatória (sem qualquer viés em sua construção). Os resultados estão presentes na Figura 6.5.

De forma similar, os resultados foram testados para redes com $n=50$ e para diferentes topologias, com exceção da medida determinística, computacionalmente inviável. Os resultados para funções IMP determinísticas e funções Canalizadoras estão presentes nas Figuras 6.6 e 6.7. 


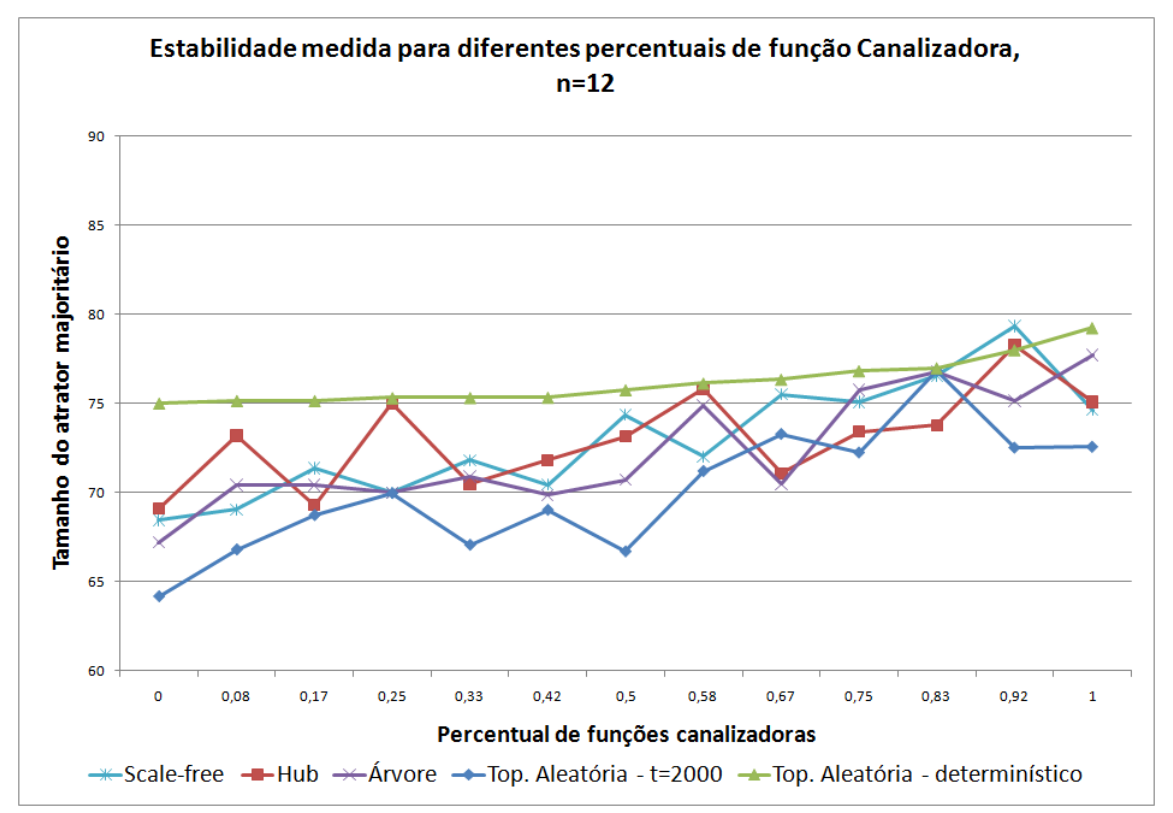

Figura 6.5: Estabilidade medida em diferentes topologias e diferentes percentuais de função Canalizadora, rede com $n=12$.

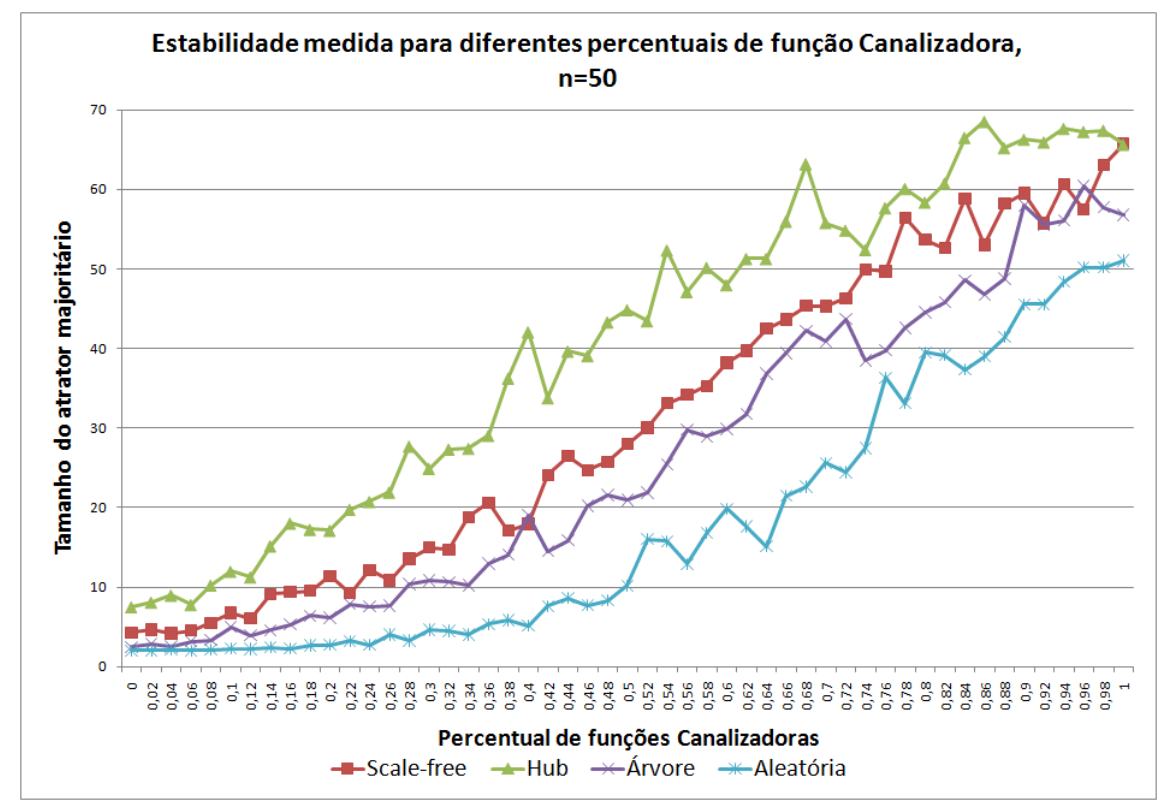

Figura 6.6: Estabilidade medida em diferentes topologias e diferentes percentuais de função Canalizadora, rede com $n=50$. 


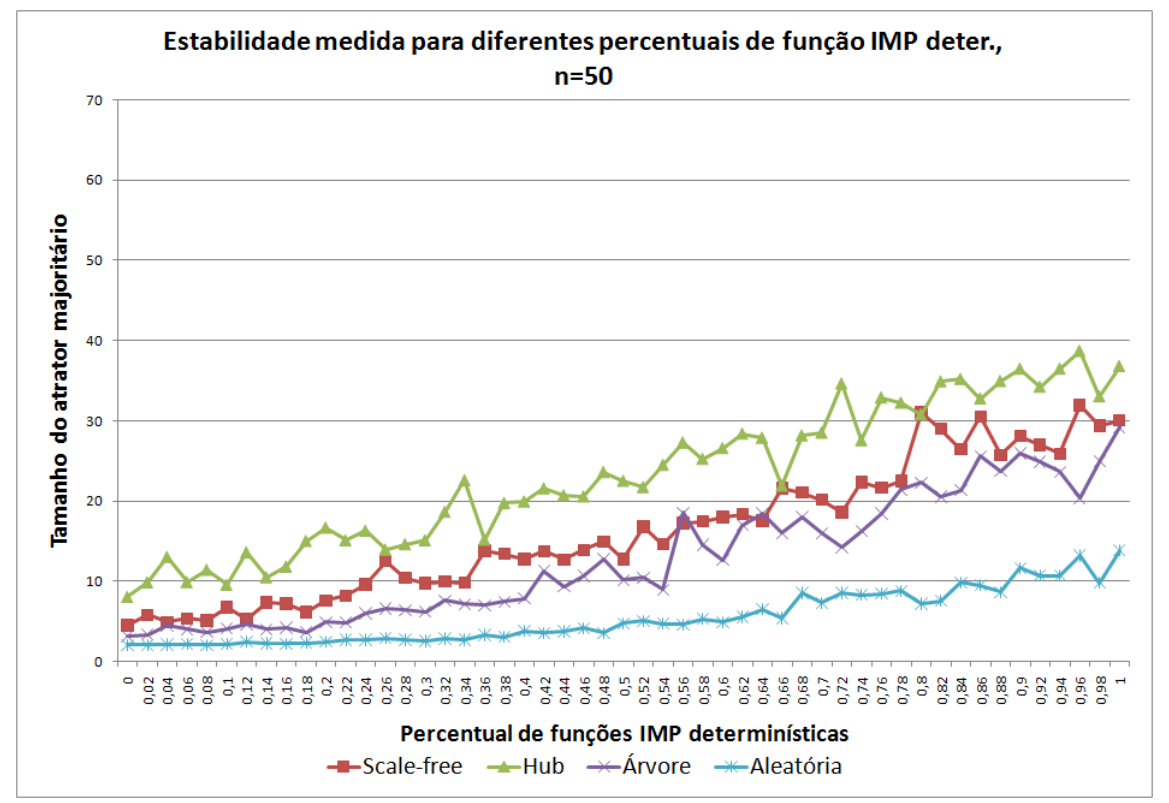

Figura 6.7: Estabilidade medida em diferentes topologias e diferentes percentuais de função IMP determinística, rede com $n=50$.

\subsection{Discussão}

A aplicação da metodologia proposta em uma rede pequena - Figura 6.5 - indica sua validade para uma avaliação qualitativa dos resultados. É possível perceber que as curvas construídas através de amostragem seguem o mesmo comportamento da medida determinística. Como é difícil caracterizar topologias de rede para poucas quantidades de nós, não é possível perceber quaisquer diferenças entre curvas provenientes de topologias distintas.

Em redes com $n=50$, distinções entre topologias e funções Booleanas já podem ser observadas. Em uma análise inicial, podemos comparar os dois gráficos expostos - Figuras 6.6 e 6.7 - em relação ao percentual que o atrator majoritário atinge em redes com grande quantidade da respectiva classe de função Booleana, ficando evidente que redes com funções Canalizadoras possuem consistentemente maior estabilidade para qualquer topologia apresentada.

Outro aspecto comum aos dois gráficos é a ordenação das topologias em relação à estabilidade. Em ambos os conjuntos de funções a ordem encontrada para a estabilidade foi:

$$
\text { hubs } \rightarrow \text { livre de escala } \rightarrow \text { Árvore } \rightarrow \text { Topologia Aleatória. }
$$

Intuitivamente, essa ordenação pode ser explicada. Redes com um hub central acabam possuindo um nó com grande capacidade de regulação. Uma vez que esse nó esteja submetido a uma função promotora de "estabilidade local", todos os demais nós da rede acabam recebendo os efeitos dessa estabilidade. Redes livres de escala também possuem uma quantidade considerável de hubs, propiciando essa transmissão da estabilidade. A topologia em árvore, mesmo sendo semelhante à topologia aleatória, também consegue influir positivamente nessa transmissão de estabilidade.

Esse resultado confirma o trabalho de Vilas Boas et. al [1], de acordo com o qual as redes livres de escala e as redes com hubs muito conectados em geral apresentam maior estabilidade para a maioria das medidas típicas de redes complexas. 
É possível também notar algumas características específicas de cada gráfico. Em redes construídas a partir de funções IMP determinísticas, as diferenças entre as topologias são menos evidentes do que em redes de funções Canalizadoras. De fato, para funções IMP determinísticas, a diferença entre a topologia livre de escala e a topologia em árvore é pouco significativa. A partir dessa informação, podemos concluir que a "estabilidade local" promovida pelas funções IMP determinística é menor do que a promovida pelas funções Canalizadoras.

Outra diferença notável é o comportamento assintótico entre as curvas de diferentes topologias e diferentes funções Booleanas. A estabilidade da topologia em hub e da topologia livre de escala aparenta seguir uma função linear do percentual de funções de uma mesma classe, em ambos os gráficos. No entanto, as topologias árvore e aleatória apresentam uma mudança qualitativa entre as funções Booleanas, já que para funções Canalizadoras elas seguem uma função exponencial e, na IMP determinísticas, uma função linear.

\subsection{Conclusão}

A interação entre topologias e funções Booleanas estudada neste capítulo indica que esses fatores devem ser analisados conjuntamente no estudo da estabilidade de redes Booleanas. Os resultados indicam que diferentes funções Booleanas têm comportamentos distintos em redes com diferentes topologias.

Um ponto interessante a ser analisado é o impacto dos resultados obtidos em possíveis redes Biológicas. Segundo a associação tamanho do atrator majoritário e canalização de características, a Figura 6.6 indica que, se cerca de 30\% dos genes forem regulados por uma função Canalizadora e a rede possuir um hub central, a bacia de atração da rede alcança um patamar considerável, agrupando cerva de $30 \%$ dos estados possíveis.

Esse tipo de análise nos leva a especular sobre a quantidade de funções Booleanas de um certo conjunto, promotor de estabilidade, presente em uma rede biológica responsável pela regulação de uma característica canalizada. Como podemos perceber, com a topologia correta, uma rede não necessita que um número elevado de genes esteja submetido a uma classe de funções, o que poderia tornar inviável o processo evolutivo formador da mesma. De fato, podemos considerar que menos da metade dos genes de uma rede com topologia não-trivial (hubs e livre de escala) precisam estar restritos a um determinado conjunto de funções Booleanas.

É claro que muitos outros fatores promotores de estabilidade local e global poderiam ser investigados. Em trabalhos futuros, a interação entre outros conjuntos de funções Booleanas e as topologias apresentadas poderiam ser investigadas. É possível que, para determinados conjuntos de funções, a ordenação encontrada aqui de estabilidade de topologias seja alterada.

Uma abordagem interessante desse ponto para o problema de inferência de redes seria a resposta à seguinte pergunta: Que conjunto de funções Booleanas, com cardinalidade e diversidade adequadas, em uma dada topologia, conferiria maior estabilidade? Uma busca exaustiva no espaço de funções Booleanas poderia ser realizada para a construção desse conjunto.

Podemos concluir que simples considerações independentes sobre topologias ou funções Booleanas são inviáveis na modelagem de canalização de características. A interação entre esses dois fatores implica em uma estabilidade mais adequada para descrever uma rede canalizada. 


\section{Capítulo 7}

\section{Conclusão}

O estudo de canalização de características sob o ponto de vista computacional é capaz de fornecer importantes orientações para a análise biológica do tema. Os assuntos tratados neste trabalho procuram interpretar o impacto dos resultados obtidos em potenciais redes biológicas. Nesta seção, resumimos as principais conclusões apresentadas.

O primeiro ponto discutido neste trabalho foi a validade do tamanho da maior bacia de atração como referência para a canalização de uma rede regulação. Evidentemente, muitas outras medidas poderiam ser adotadas, mas, neste trabalho, percebemos que a utilização desse atributo consegue reunir interpretações biológicas e matemáticas favoráveis. Dessa forma, podemos concluir que essa medida é adequada para a avaliação da canalização de uma rede.

Considerações sobre funções Booleanas mais adequadas para modelagem de canalização foram realizadas no Capítulo 4. Confirmando os resultados da literatura, funções Canalizadoras apresentam um bom desempenho na promoção de estabilidade, assim como o conjunto de funções IMP determinísticas, introduzidas neste trabalho.

No Capítulo 5, foram feitas análises sobre a influência da conectividade dos genes na canalização de uma rede. É possível concluir que a estabilidade aumenta com a conectividade da rede, o que pode indicar um fator necessário a ser exibido por uma rede canalizada.

Juntamente com esse resultado, investigamos a interação entre funções Booleanas e topologia da rede de regulação. É possível concluir que esses dois temas estão fortemente relacionados e qualquer análise de estabilidade em redes biológicas com muitos genes deve considerar esses dois fatores conjuntamente. Os resultados também indicam que redes em que um hub central é predominante e apenas cerca de $30 \%$ de funções são funções Canalizadoras apresentam boa estabilidade e poderiam ser redes de uma característica canalizada.

Cabe ressaltar as dificuldades encontradas em validar os resultados aqui obtidos com dados biológicos de laboratório. Mesmo a validação do tamanho da bacia de atração como medida de canalização, que dependeria de experimentos conceitualmente mais simples, foi possível de ser realizada apenas para uma rede muita pequena. Entendemos que a falta de respaldo biológico de nossas conclusões é um ponto de risco deste trabalho, logo, procuramos tratar nossos resultados mais como orientações para futuros experimentos biológicos sobre o tema.

Em trabalhos futuros, seria interessante realizar o caminho lógico reverso deste trabalho: Quais os fatores mais importantes de uma rede para a manutenção de sua estabilidade? Estudos sobre o risco de uma rede, biológica ou não, perder sua estabilidade são promissores em nosso cenário atual, no qual estão em pauta preocupações com doenças tipicamente gênicas - como o câncer - e também com, estendendo para outros 
domínios, crises no sistema financeiro.

Como conclusão geral, é possível afirmar que este trabalho é um exemplo de como simulações e modelos matemáticos - estudos típicos de bioinformática - podem ajudar na interpretação e na caracterização de um problema biológico - a canalização de características. 


\section{Bibliografia}

[1] P. R. V. Boas, F. A. Rodrigues, G. Travieso, and L. F. Costa. Sensitivity of complex networks measurements. Journal of Statistical Mechanics: Theory and Experiment, 2010. 43

[2] G. Boldhaus, N. Bertschinger, J. Rauh, E. Olbrich, and K. Klemm. Robustness of boolean dynamics under knockouts. PHYSICAL REVIEW E, (82), 2010. 11, 27

[3] S. Bornholdt. Boolean network models of cellular regulation: prospects and limitations. J. R. Soc. Interface, (5):S85-S94, 2008. 10

[4] D. K. Breslow, D. M. Cameron, S. R. Collins, M. Schuldiner, J. Stewart-Ornstein, H. W. Newman, S. Braun, H. D. Madhani, N. J. Krogan, and J. S. Weissman. A comprehensive strategy enabling high-resolution functional analysis of the yeast genome. Nature Methods, 5:711-718, 2008. 33, 34

[5] J. V. Buskirk and U. K. Steiner. The fitness costs of developmental canalization and plasticity. Journal of Evolutionary Biology, 22:852-860, 2009. 5

[6] E. R. Dougherty, M. Brun, J. Trent, and M. L. Bittner. A Conditioning-Based Model of Contextual Regulation. IEEE/ACM Transactions on Computational Biology and Bioinformatics, 2007. 9

[7] E. R. Dougherty and Y. Xiao. Design of Probabilistic Boolean Networks under the Requirement of Contextual Data Consistency. IEEE Transactions on Signal Processing, 54(9):3603-3613, 2006. 9

[8] J. M. Emlen, D. C. Freeman, A. Mills, and J. H. Graham. How organisms do the right thing: The attractor hypothesis. CHAOS, 8:717-727, 1998. 5

[9] I. Eshel and C. Matessi. Canalization, genetic assimilation and preadaptation: A quantitative genetic model. Genetics, 149:2119-2133, 1998. 5

[10] A. Esmaeili and C. Jacob. A multi-objective differential evolutionary approach toward more stable gene regulatory networks. BioSystems, (98):127-136, 2009. 11

[11] N. Friedman, M. Linial, I. Nachman, and D. Pe'er. Using Bayesian Network to Analyze Expression Data. Journal of Computational Biology, 7:601-620, 2000. 7

[12] J. Grefenstette, S. Kim, and S. Kauffman. An analysis of the class of gene regulatory functions implied by a biochemical model. BioSystems, (84):81-90, 2006. 40

[13] T. F. Hansen and G. P. Wagner. Modeling genetic architecture: A multilinear theory of gene interaction. Theoretical Population Biology, 59:61-86, 2001. 5 
[14] M. Hayashida, T. Tamura, T. Akutsu, Shu-Qin, Zhang, and W.-K. Ching. Algorithms and complexity analyses for control of singleton attractors in boolean networks. EURASIP Journal on Bioinformatics and Systems Biology, (2008), 2008. 11

[15] C. H. A. Higa, V. H. P. Louzada, and R. F. Hashimoto. Analysis of gene interactions using restricted boolean networks and time-series data. Springer Verlag Lecture Notes in Bioinformatics, 2010. 1, 10, 18

[16] E. Hornstein and N. Shomron. Canalization of development by micrornas. Nature Genetics, 38:20-24, 2006. 5

[17] S. ichi Kinoshita, K. Iguchi, and H. S.Yamada. Intrinsic properties of boolean dynamics in complex networks. Journal of Theoretical Biology, (256):351-369, 2009. 40

[18] K. Iguchi, S. ichi Kinoshita, and H. S. Yamada. Boolean dynamics of kauffman models with a scale-free network. Journal of Theoretical Biology, (247):138-151, 2007. 40

[19] N. G. I. Ivanov, X. Qian, and E. R. Dougherty. A cod-based reduction algorithm for designing stationary control policies on boolean networks. Bioinformatics, 26(12):1556-1563, 2010. 11

[20] A. S. Jarrah, B. Raposab, and R. Laubenbachera. "nested canalyzing, unate cascade, and polynomial functions". Physica D, 233:167-174, 2007. 14

[21] R. L. Jirtle and M. K. Skinner. Environmental epigenomics and disease susceptibility. Nature Reviews, 8:253-262, 2007. 3

[22] H. D. Jong. Modeling and Simulation of Genetic Regulatory Systems: A Literature Review. Journal of Computational Biology, 9(1):67-103, 2002. 7

[23] S. Kauffman. Metabolic Stability and Epigenesis in Randomly Constructed Genetic Nets. Journal of Theoretical Biology, 22:437-467, 1969. 7, 9, 10, 20

[24] S. Kauffman. Gene regulation networks: A theory for their global structure and behaviors. Current Topics in Developmental Biology, 6:145-182, 1971. 6, 13, 14

[25] S. Kauffman. The Origins of Order: Self-Organization and Selection in Evolution. Oxford University Press, USA, 1 edition, June 1993. 10, 14, 20

[26] S. Kauffman, C. Peterson, B. Samuelsson, and C. Troein. Random boolean transcriptional networks with nested canalyzing function. Proceedings of the National Academy of Sciences, page 14796-14799, 2003. 14

[27] S. Kauffman, C. Peterson, B. Samuelsson, and C. Troein. "genetic networks with canalyzing boolean rules are always stable". Proceedings of the National Academy of Sciences, 101:17102-17107, 2004. 14

[28] T. Kimbrell and R. D. Holt. Canalization breakdown and evolution in a source-sink system. The American Naturalist, 169:370-382, 2007. 5

[29] H. Kitano. Biological robustness. Nature Genetics, 5:826-837, 2004. 1

[30] H. Kitano. Towards a theory of biological robustness. Molecular Systems Biology, 3(137), 2007. 1 
[31] K. Kobayashi, J.-I. Imura, and K. Hiraishi. Polynomial-time algorithm for controllability test of a class of boolean biological networks. EURASIP Journal on Bioinformatics and Systems Biology, (2010), 2010. 11

[32] P. Krawitz and I. Shmulevich. Basin entropy in boolean network ensembles. PHYSICAL REVIEW LETTERS, (98):2007. 11

[33] F. Li, T. Long, Y. Lu, Q. Ouyang, and C. Tang. The Yeast Cell-Cycle Network is Robustly Designed. Proceedings of the National Academy of Sciences of the United States of America, 101(14):4781-4786, 2004. 10, 22, 30, 31

[34] D. C. Martins, E. A. de Oliveira, V. H. Louzada, and R. F. Hashimoto. Inference of restricted stochastic boolean grn's by bayesian error and entropy based criteria. Lecture Notes in Computer Science, 6419:144-152, 2010. 1

[35] D. C. Martins, R. F. Hashimoto, U. Braga-Neto, E. R. Dougherty, and M. L. Bittner. Intrinsically Multivariate Predictive Genes. IEEE Journal of Selected Topics in Signal Processing, 2008. Accepted Paper. 15

[36] T. Mestl, E. Plahte, and S. W. Omholt. A Mathematical Framework for Describing and Analysing Gene Regulatory Networks. Journal of Theoretical Biology, 176:291-300, 1995. 7

[37] A. A. Moreira and L. A. N. Amaral. "canalizing kauffman networks: Nonergodicity and its effect on their critical behavior". Phys Rev Lett, 94:218702, 2005. 14

[38] R. Pal, A. Datta, M. L. Bittner, and E. R. Dougherty. Intervention in Context-Sensitive Probabilistic Boolean Networks. Bioinformatics, 21(7):1211-1218, 2005. 9

[39] T. P. Peixoto and B. Drossel. Noise in random boolean networks. PHYSICAL REVIEW E, (79), 2009. 11

[40] A. Pomerance, E. Ott, M. Girvan, and W. Losert. The effect of network topology on the stability of discrete state models of genetic control. Proceedings of the National Academy of Sciences, 106(20):8209-8214, 2009. 40

[41] E. Post. Am. J. Math., (43):163-185, 1921. 17

[42] E. Post. Two-valued iterative systems of mathematical logic. Princeton Univ. Press, 1941. 17

[43] S. R. Proulx and P. C. Phillips. The opportunity for canalization and the evolution of genetic networks. The American Naturalist, 165:147-162, 2005. 5

[44] A. Riegler. Natural or internal selection? the case of canalization in complex evolutionary systems. Artificial Life, 14:345-362, 2008. 5

[45] P. Rämö, J. Kesseli, and O. Yli-Harja. Stability of functions in boolean models of gene regulatory networks. CHAOS, (15), 2005. 40

[46] T. Rohlf, N. Gulbahce, and C. Teuscher. Damage spreading and criticality in finite random dynamical networks. PHYSICAL REVIEW LETTERS, (99), 2007. 11 
[47] S. L. Rutherford and S. Lindquist. Hsp90 as a capacitor for morphological evolution. Nature, 396:336342, 1998. 4

[48] B. Samuelsson and J. E. S. Socolar. Exhaustive percolation on random networks. PHYSICAL REVIEW E, (74), 2006. 11

[49] K. Sato and H. Siomi. Is canalization more than just a beautiful idea? Genome Biology, 11:1-4, 2010. 5

[50] T. Schlitt and A. Brazma. Current approaches to gene regulatory network modelling. BMC Bioinformatics, 8(S9), 2007. 7

[51] I. Shmulevich, E. R. Dougherty, S. Kim, and W. Zhang. Probabilistic Boolean Networks: A Rule-Based Uncertainty Model for Gene Regulatory Networks. Bioinformatics, 18(2):261-274, 2002. 7

[52] I. Shmulevich, H. Lahdesmaki, E. R. Dougherty, J. Astola, and W. Zhang. "the role of certain post classes in boolean network models of genetic networks". Proceedings of the National Academy of Sciences, 100:10734-10739, 2003. 17, 18

[53] C. Sima, J. Hua, and S. Jung. Inference of gene regulatory networks using time-series data: A survey. Current Genomics, 10:416-429, 2009. 7

[54] P. T. Spellman, G. Sherlock, M. Q. Zhang, V. R. Iyer, K. Anders, M. B. Eisen, P. O. Brown, D. Botstein, and B. Futcher. Tbd. Mol. Biol. Cell, 9:3273-3297, 1998. 30

[55] S. C. Stearns. Progress on canalization. Proceedings of the National Academy of Sciences, 99(16):10229-10230, 2002. Commentary. 4

[56] K. H. ten Tusscher and P. Hogeweg*. The role of genome and gene regulatory network canalization in the evolution of multi-trait polymorphisms and sympatric speciation. BMC Evolutionary Biology, 9, 2009. 5

[57] R. Thomas. Regulatory Networks seen as Asynchronous Automata: A Logical Description. Journal of Theoretical Biology, 153:01-23, 1991. 7

[58] G. Vahedi, I. Ivanov, and E. R. Dougherty. Inference of boolean networks under constraint on bidirectional gene relationships. Systems Biology, (3):191-202, 2009. 11

[59] C. H. Waddington. Canalization of development and the inheritance of acquired characters. Nature, 150(3811):563-565, 1942. 1, 3, 4

[60] A. Wagner. Robustness against mutations in genetic networks of yeast. Nature Genetics, 24:356-361, 2000. 4

[61] K. Willadsen and J. Wiles. Robustness and state-space structure of boolean gene regulatory models. Journal of Theoretical Biology, (249):749-765, 2007. 11

[62] C.-I. Wu, Y. Shen, and T. Tang. Evolution under canalization and the dual roles of micrornas-a hypothesis. Genome Research, 19:734-743, 2009. 5

[63] Y. Xiao. A tutorial on analysis and simulation of boolean gene regulatory network models. Current Genomics, (10):511-525, 2009. 10 
[64] Y. Xiao and E. R. Dougherty. Optimizing Consistency-Based Design of Context-Sensitive Gene Regulatory Networks. IEEE Transactions on Circuits and Systems I, 53(11):2431-2437, 2006. 9

[65] Y. Xiao and E. R. Dougherty. The impact of function perturbations in boolean networks. BIOINFORMATICS, 23(10):1265-1273, 2007. 11

[66] Y. Zhang, M. Quian, Q. Ouyang, M. Deng, F. Li, and C. Tang. Stochastic Model of Yeast Cell-Cycle Network. Physica D, 209:2006, 35-39. 10

[67] Y. M. Zou. Modeling and analyzing complex biological networks incooperating experimental information on both network topology and stable states. Bioinformatics, 26(16):2037-2041, 2010. 40 